経 営史学

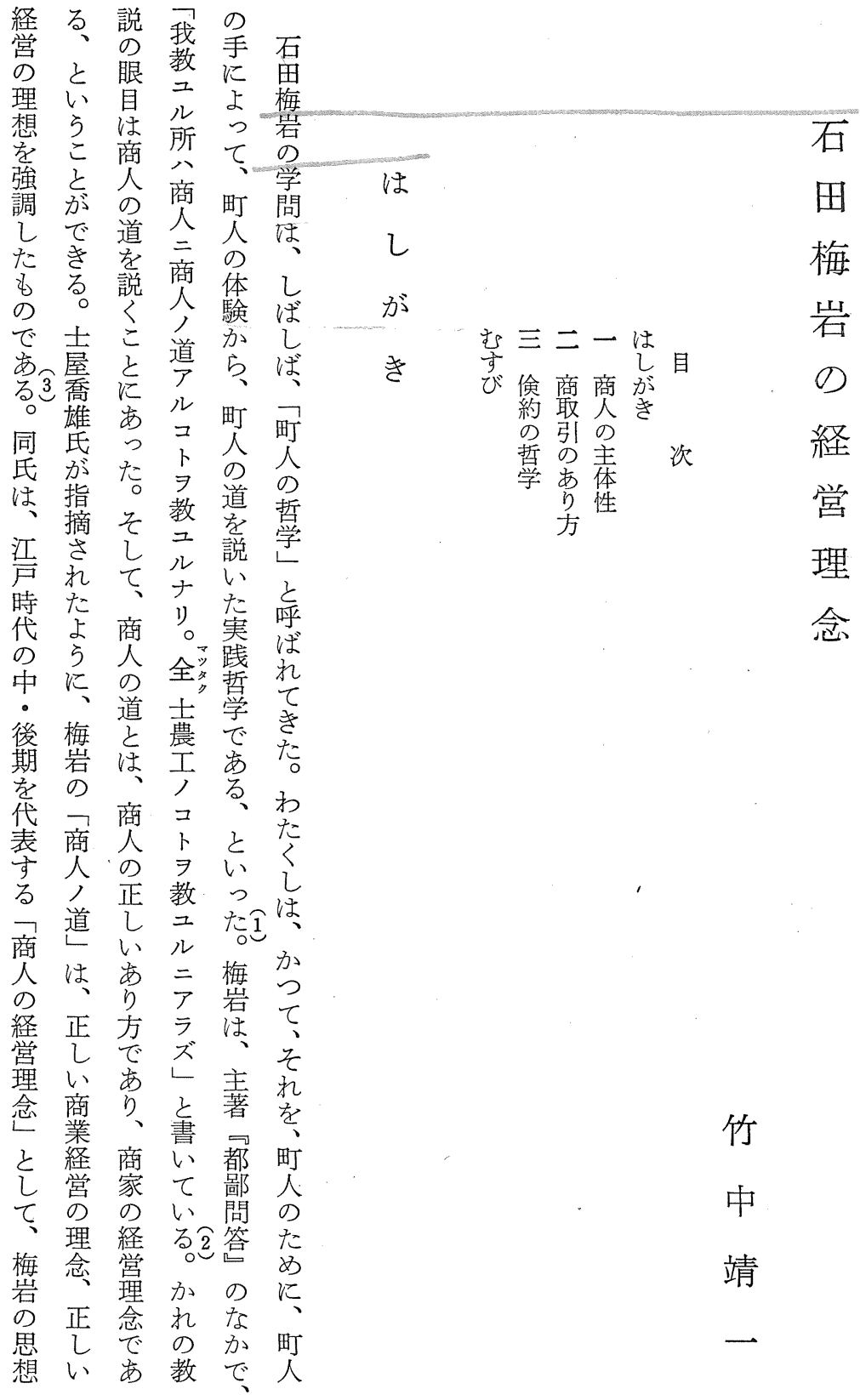


第 4 巻 第 3 号

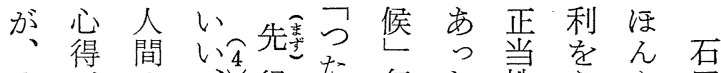
は心洦た年た性らら思

じし根西利な貢。をるい梅

め本川壳に, 博強この岩

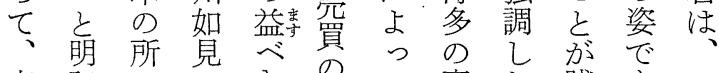

商記に注き業て豪た賤市佶

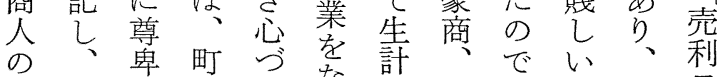

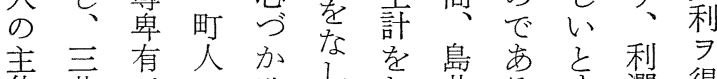

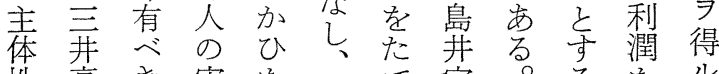

性高き実を得て宗。るをル

孝房理吕修得る臸そ思箱方商

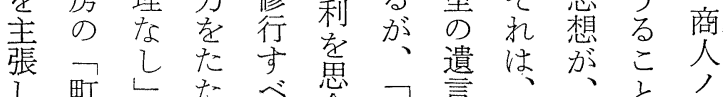

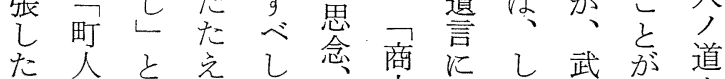

た人考主て忘念商に休武㤎道

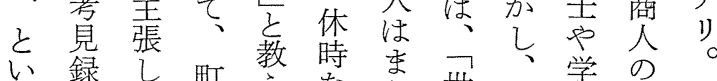

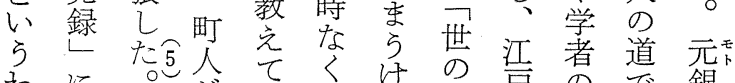

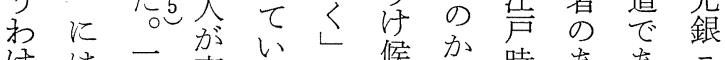

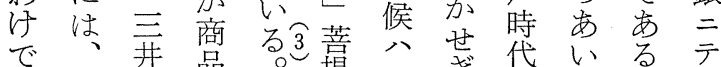

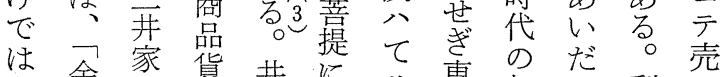

な金は僌井に六専初に利荒

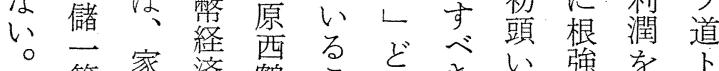

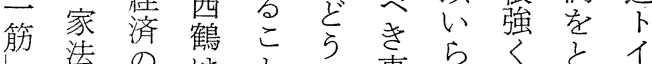

の 穴実交

のな権、㤎占生、たぬコ

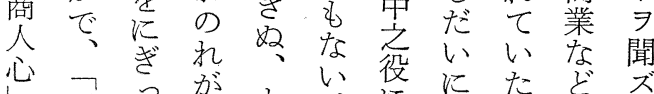

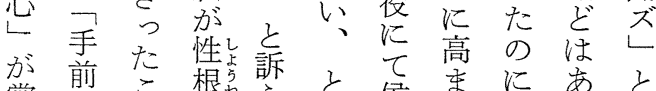

賞前こ根就光指侯まに市と

賛商を存上商摘をでい方

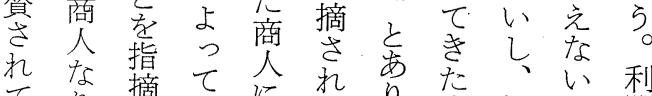

てな摘て長飞热方商梅、澗

い。方長子て、商梅子潤

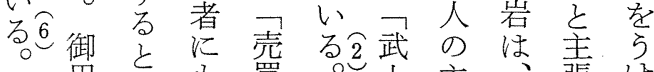

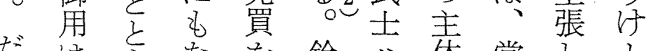

な゙は岛なを鈴領性掌た る

らの比正地のとのの

余氖严自利でが

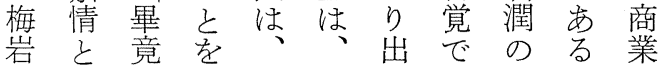

商 頁是巻学㤎

人. 経嫦経

の

主

理 或息

念学思こ

念者息に

体

性

三学六

学頁わ

真問 た

譏段市 な

柴少

寒立場

只少

奋 占

宕梅

譙岩

以 経

赑営

た念

そ を

全 険

集记

た た

点

爷 
経 営 史 学

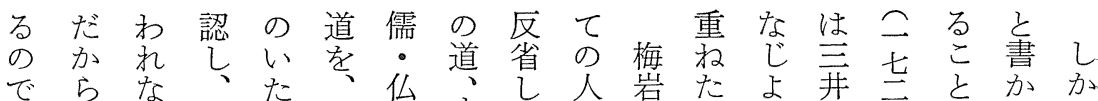

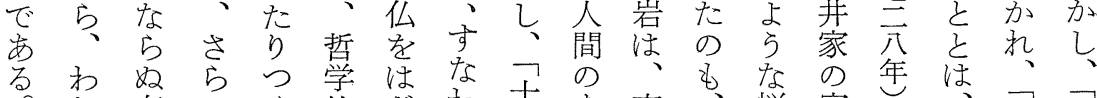

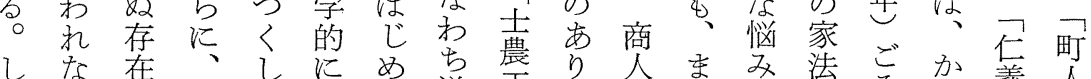

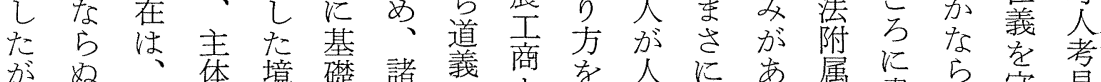

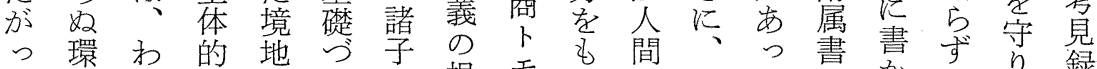

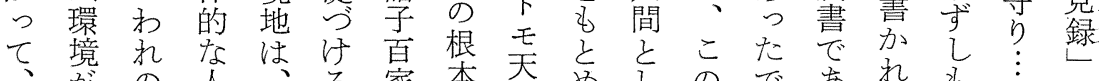

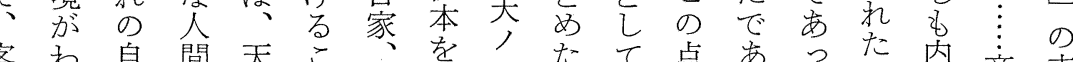

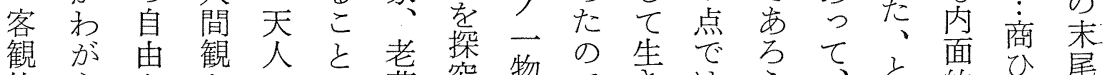

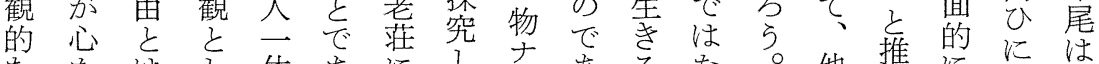

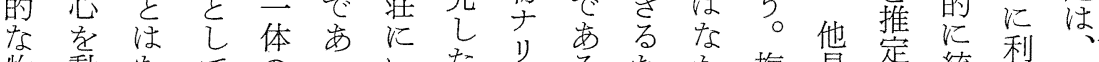
物動なて、の っいた 形古な心界た た 汃心 $心$ 。

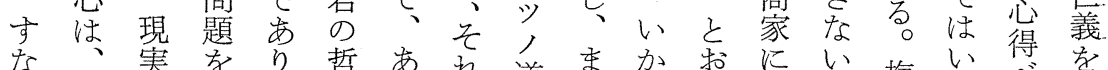
な、実をり、哲西れ道まか打にい梅い得を わ環に探、学ら值たにも奉も峟な亿離

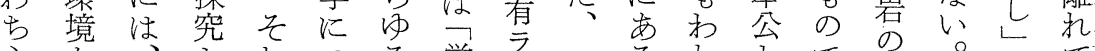

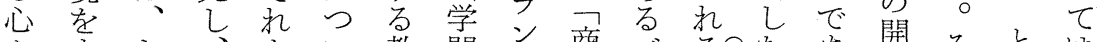

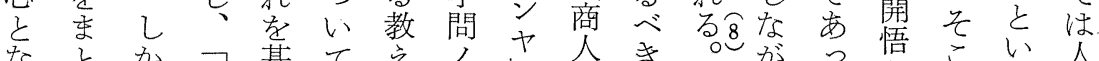

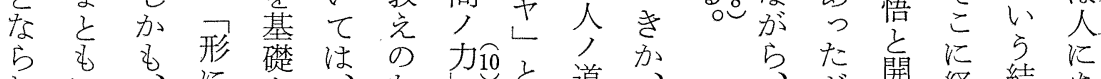

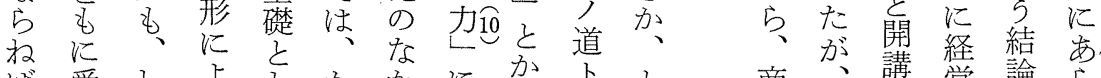

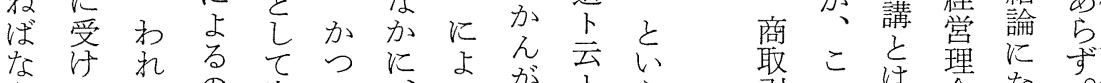

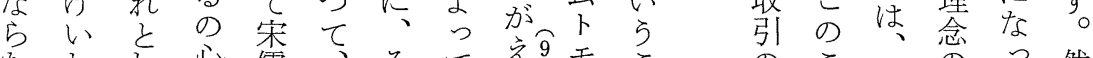

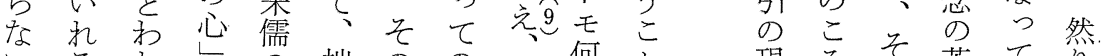

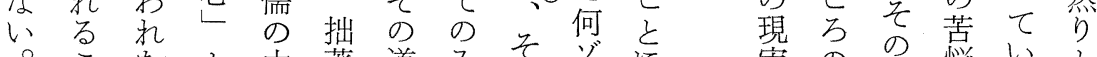

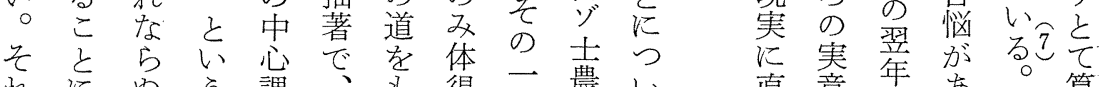

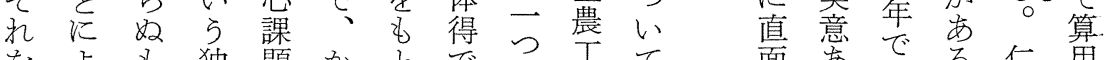

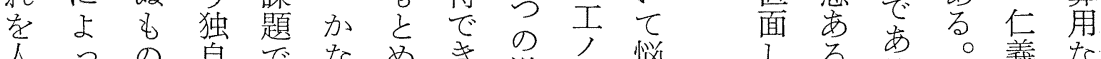
人っの自でなめき道道悩しる。る

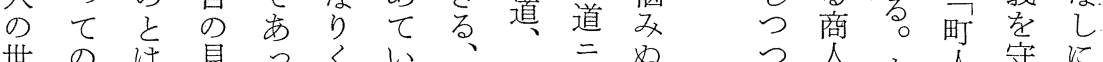

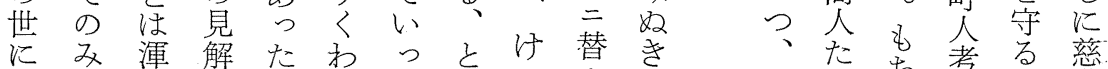

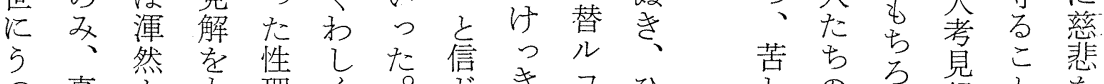

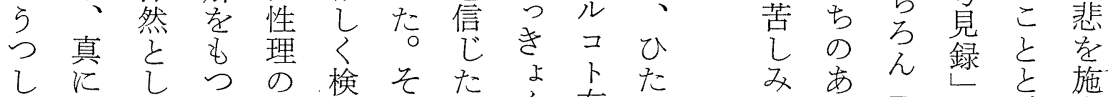

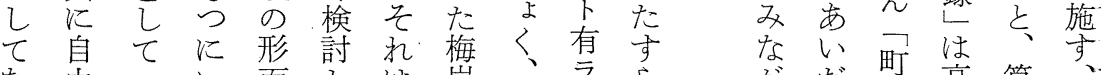
な 由

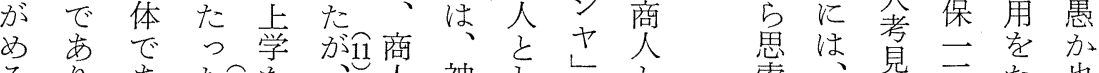

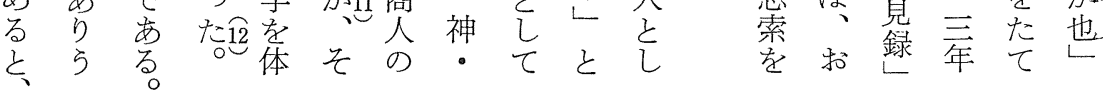


商商人を代をとたに商とて相分武 梅人人のこの町の方尔な高こめ具良で士 岩たたなろ武人言る、登をのる体亭市に

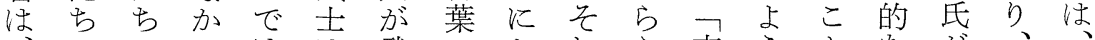

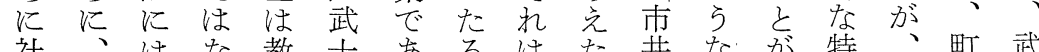
商社 、はな教士あるはた井な学特、町武 人会商、か養交る業、の, 哲で殊石人主 の的商道っ階效。績武で臣学き的石のを

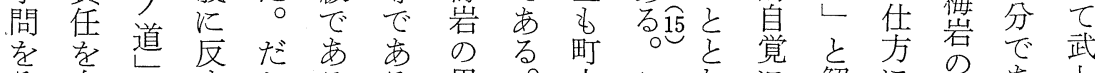

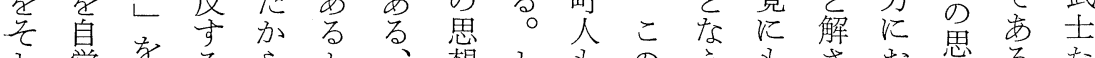

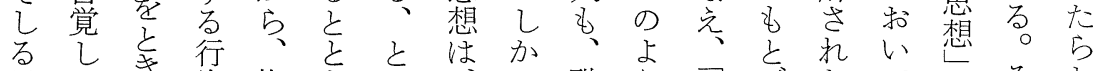

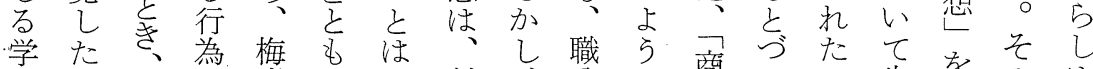
者経道を岩にい対、分に商い少生离のぬ

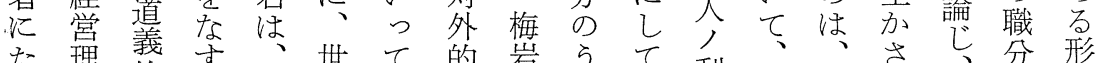
た理的す、世て的岩引て、利、分形 い念的も商のもなの省、梨梅まれ子をが 乙鼻の人師、抗こでか岩さ称人ら市 て確学驾も表々議のは机を注にば間々り

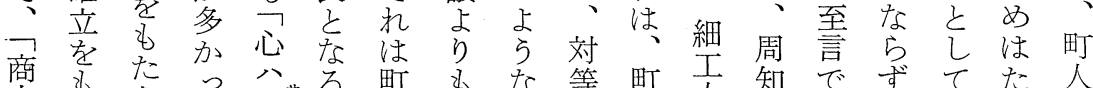

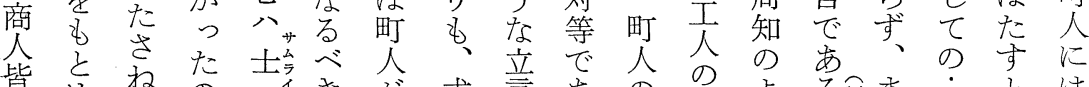

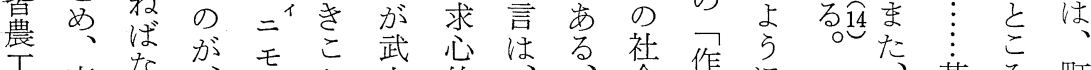

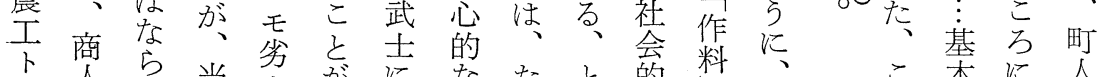

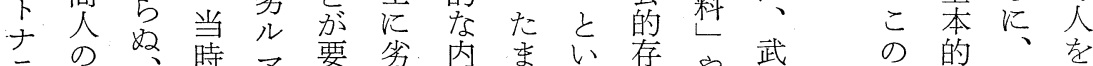
ラ の、時、要劣内市い存や武的、を 心媇とのジ求ら省たら立農家こな武し

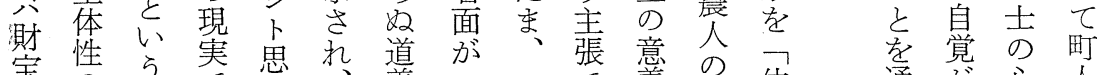

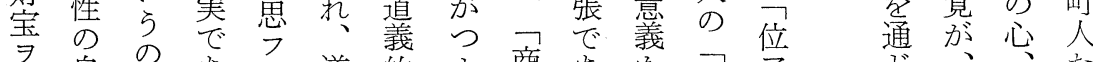

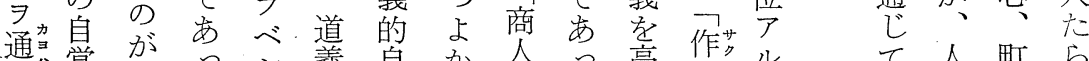

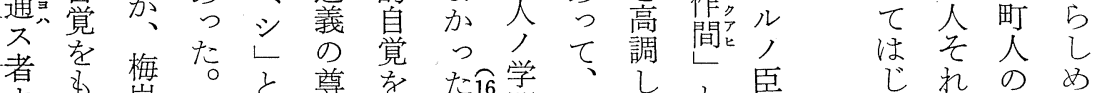

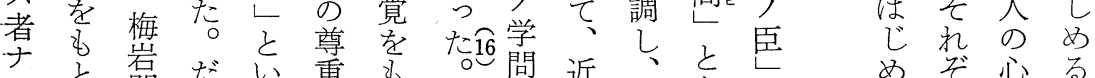

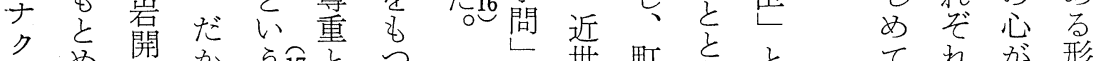

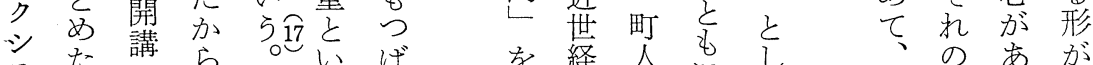

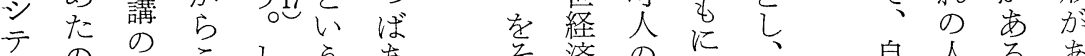

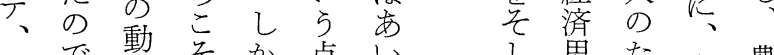
万で䑦々か点いの㥁た想め農

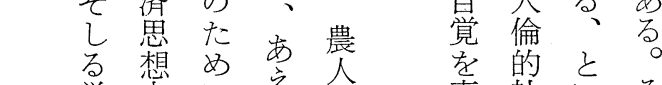

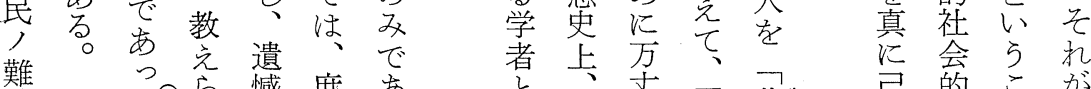

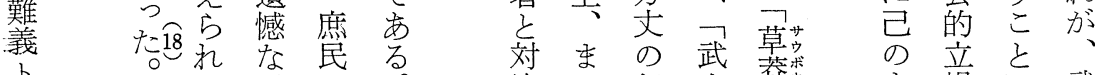

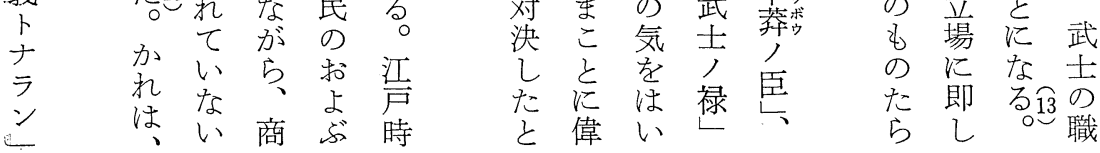


経営史学

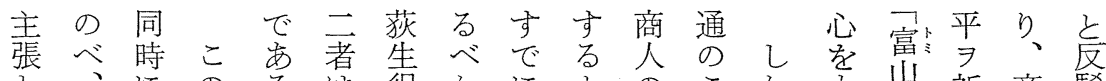

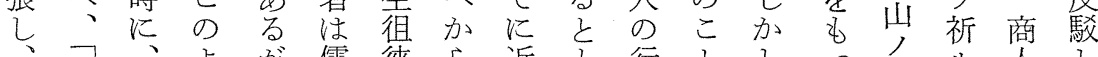

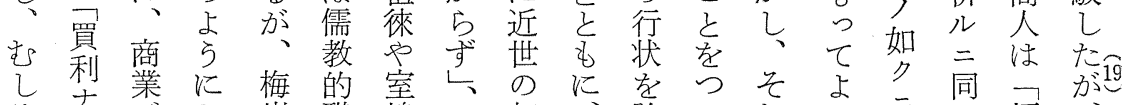

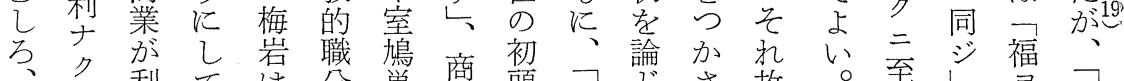

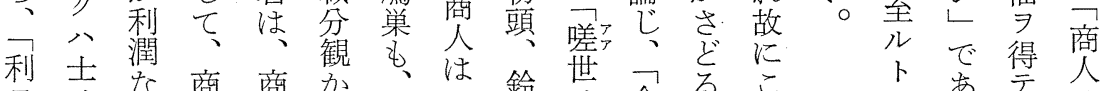

$\Rightarrow$ 广な商商㤎士

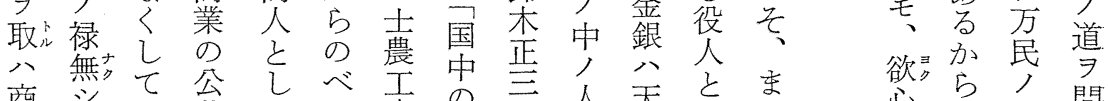

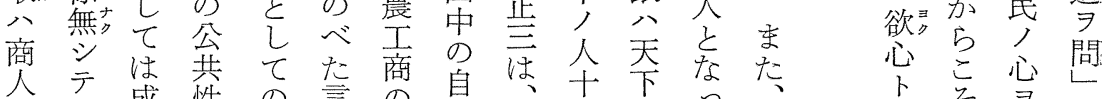

人テッ成性の言商自は、十草なた

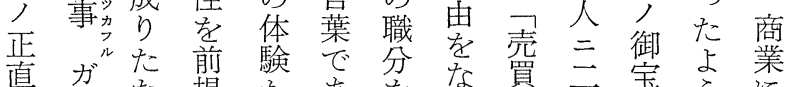

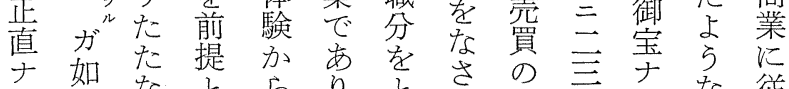

り 如な

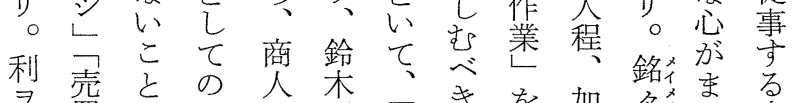

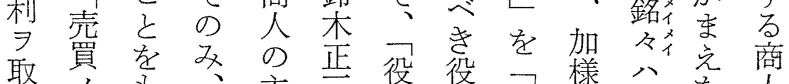

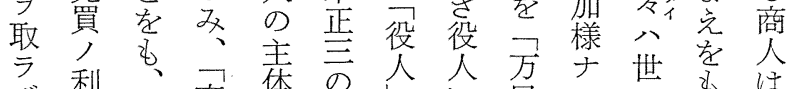

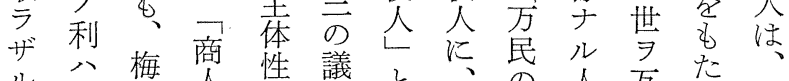

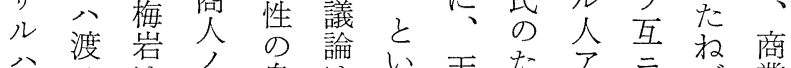

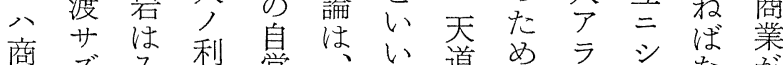

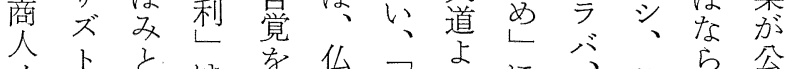

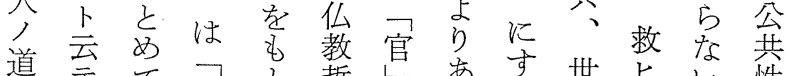

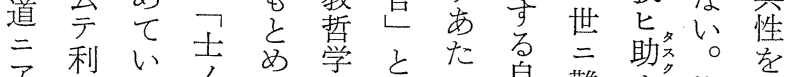

ア 利いる る

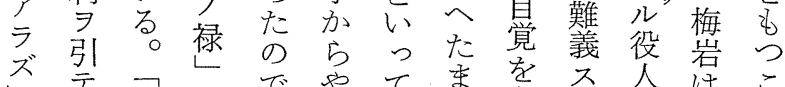

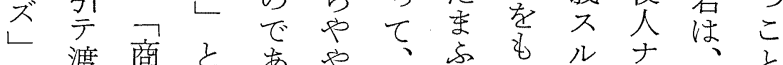

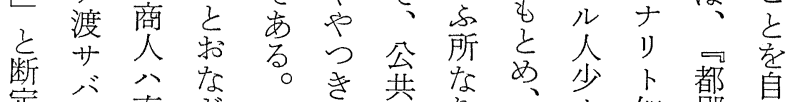

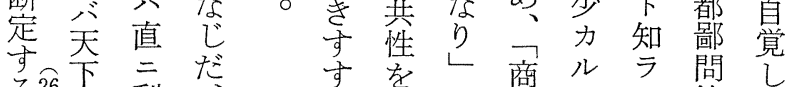

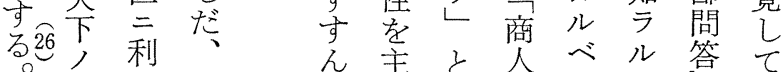

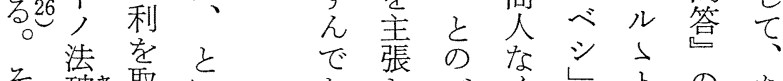

そ破取いかし心゙くし占のあ

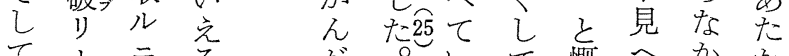

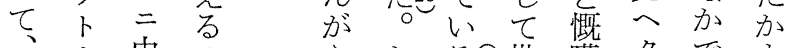

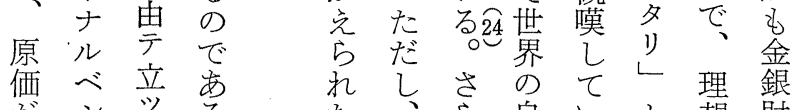

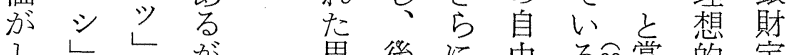

乙 るとと、想の、㐫賛な流 


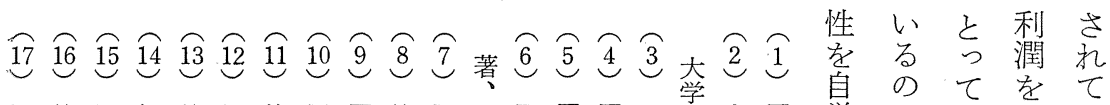

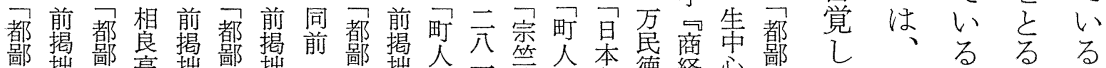

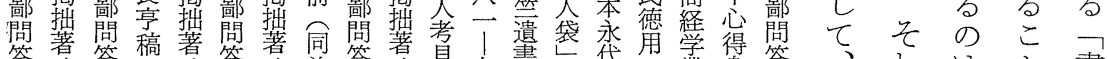

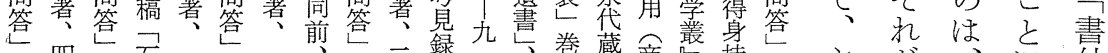

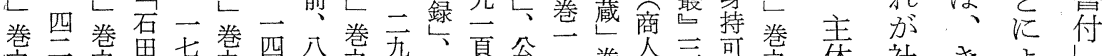

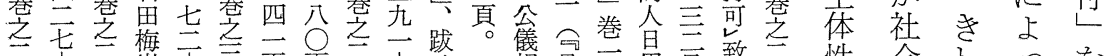

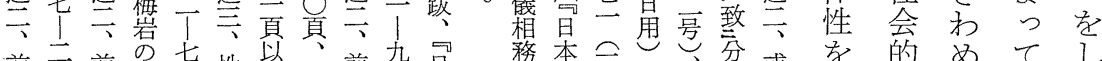

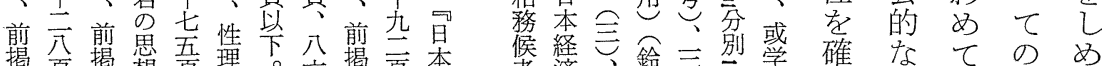

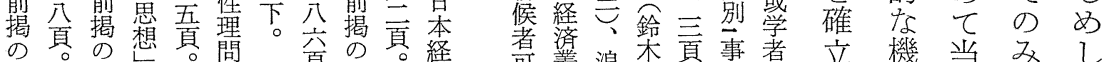

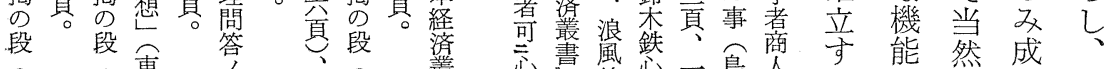

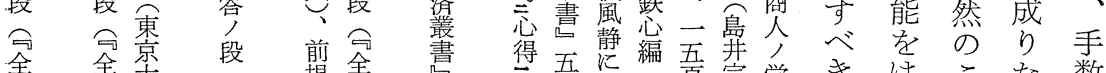

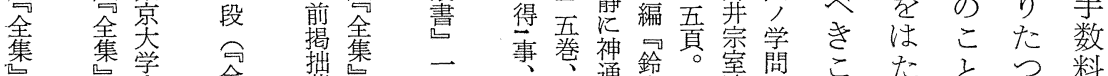

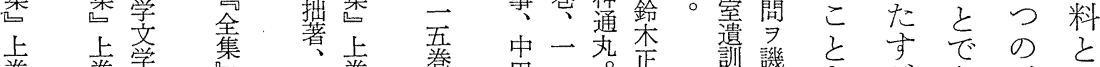

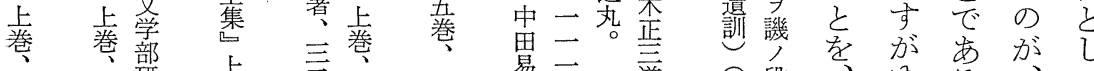

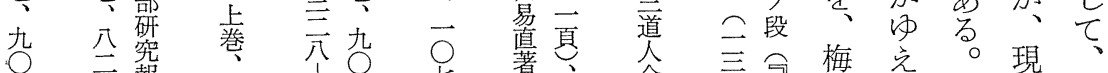

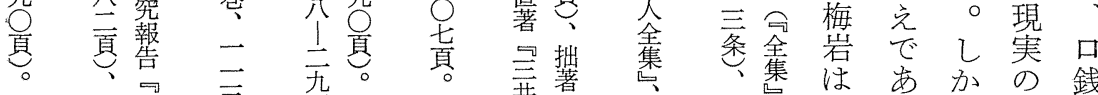

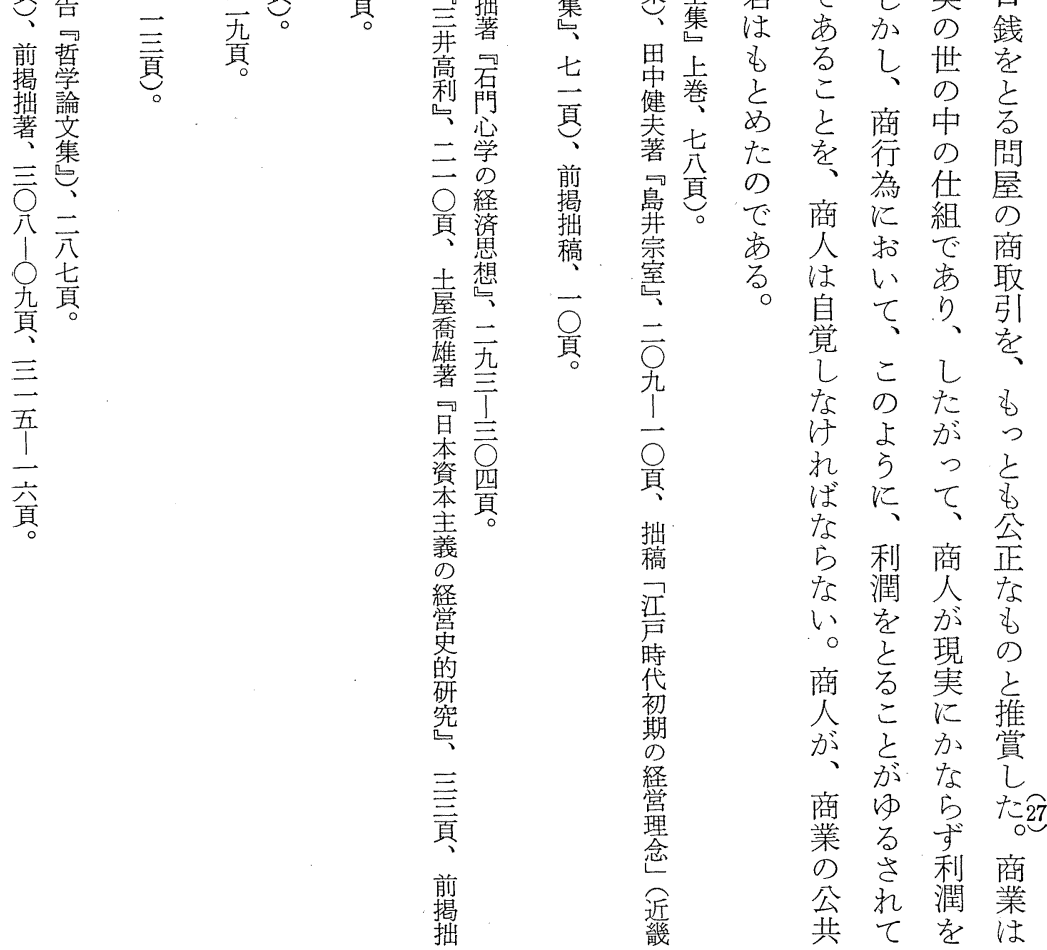




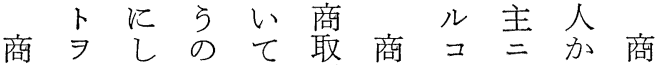
取思なは取引取トアら人

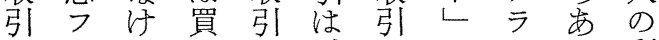
とナれいが、は学ズた利 いリば手成二、息ヤ学が らとをな

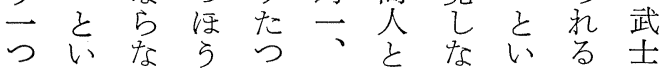
のっいにの方活ら方の

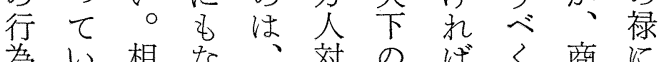

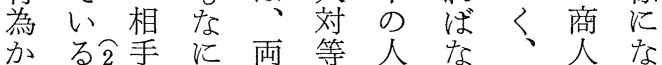
ら 方 ら者学

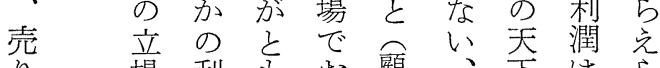
り場利多扰顧、午は占 手を益にこ客との不れ 厙尊㤎取な子梅人特る

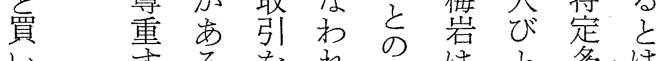
いするをれを劣多は

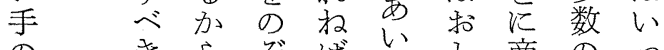

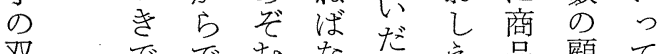

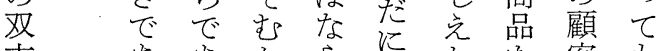

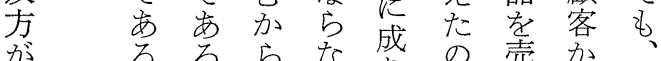

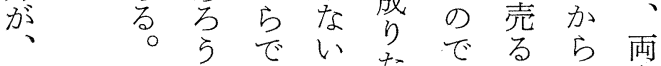

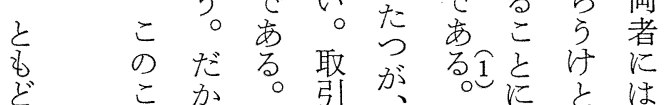
ぞ こ か

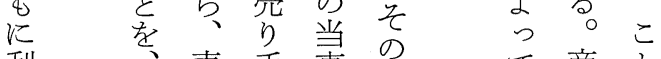
利志手事 益梅りだ者 を岩手沪学 ら惊㟔双

な

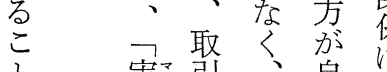
之実引 自住

で商相貝㕣か る 商手手交交 そ 先江取 今゙

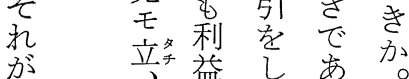
商

取 の 浮 生に苔に がとと だつこ る住㤎 の、あ 坛天る 吊, 武 偊少声 声势奉、 中竞定 禄筫主 て 商 こ 貨务我 禄 禄禄 定

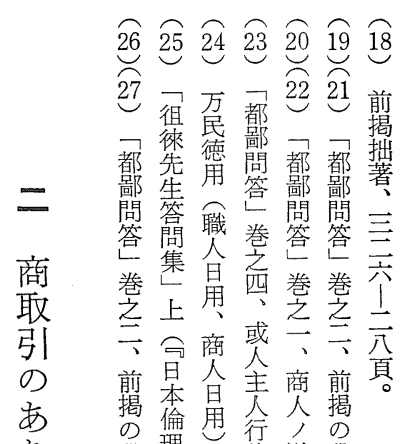

り段理壆状道段 方令編鈴是問全 集巻鉄非段隹 卷亲編問会路 七五查焦八 貣頁道售卷六 八元全卷恶貝 公忘集一息。 賸圥 忘

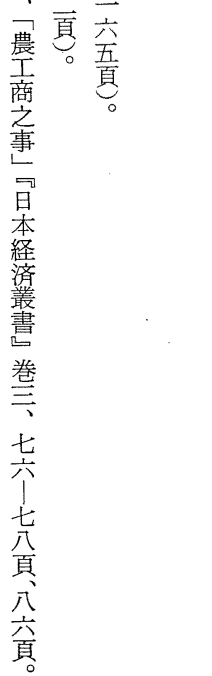


第 4 巻 第 3 号

臣光心造とを惜を売取事喜け売几 はた相ヨ籿い、か㕕渡引自三びれりら

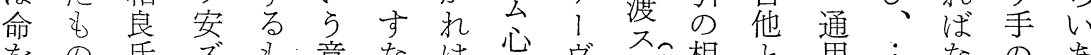

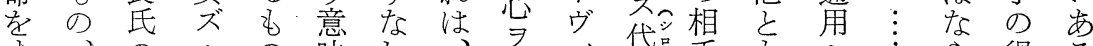

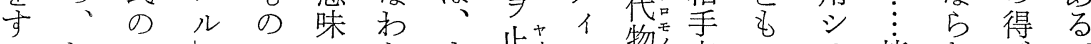

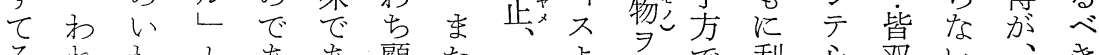

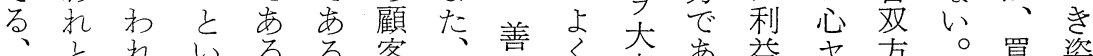

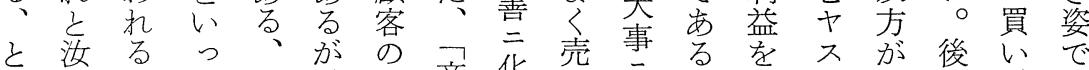

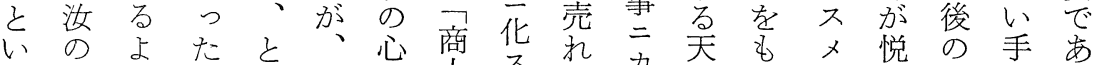
ら-

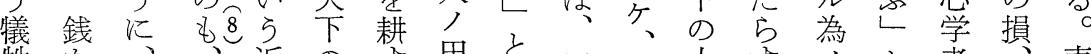

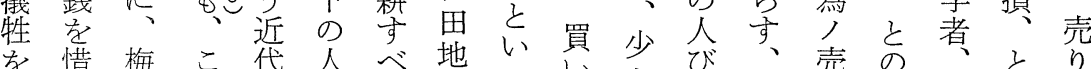

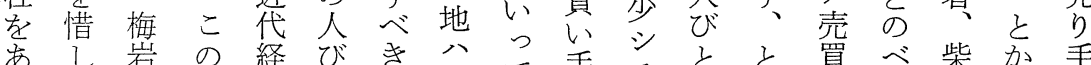

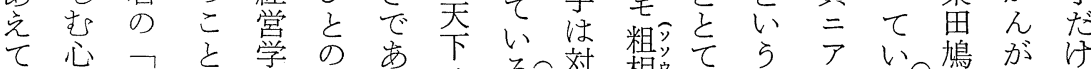
飞商の

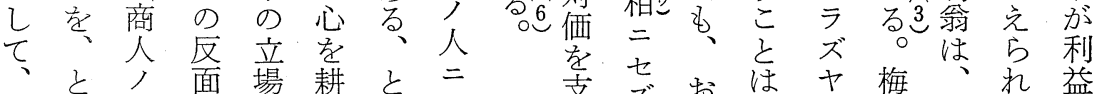

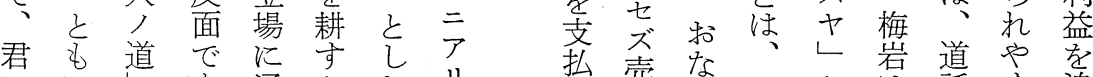

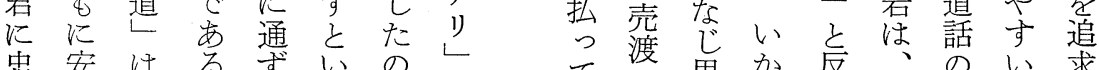
忠安

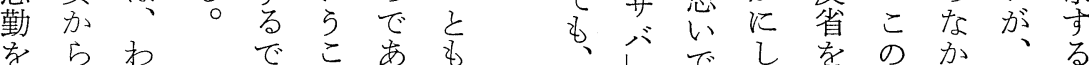
をらわ礼こ市ね

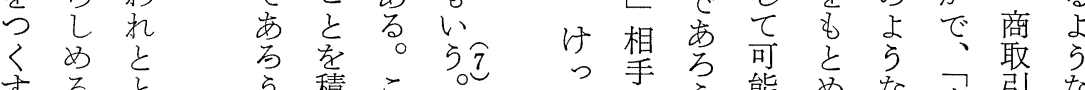
する

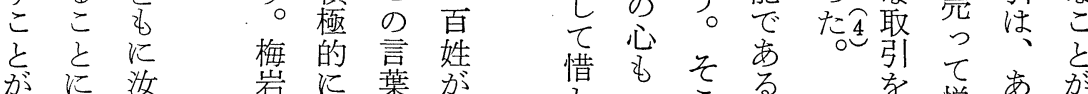

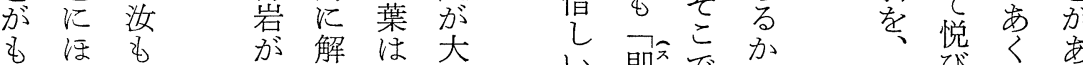

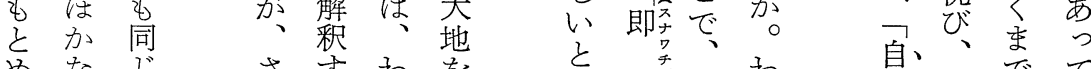

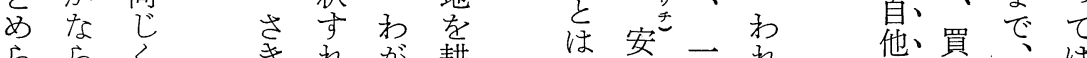

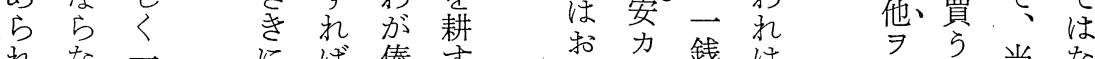

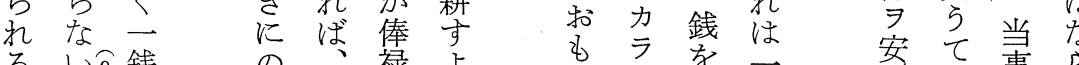

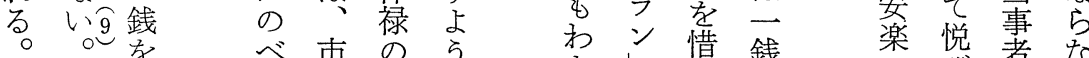

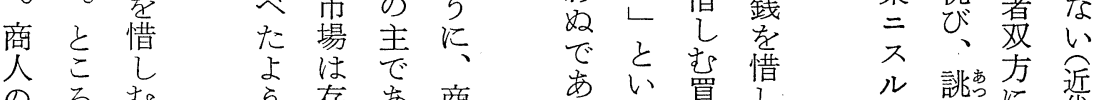
のろむ 道孞と 注在学人 天武 ら福息客天

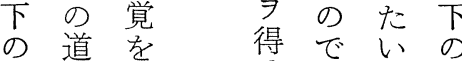
人根 び拈底

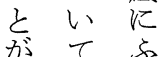
主は要

痤せ人

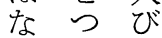

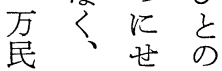
底創禁忍
万買し

多手志

梅で心を

石哥よて

そ知亟

れい杂

品て 商
ᄂ 5 利代

塬气益独

琴学占 しるた撆 自、び点量 他、据它 共据占のに 方てだ 弯 
経 営 史 学

都テる高令商もに方文我たさ 志君 度私。米”年品で固商なち的。な前あ買と

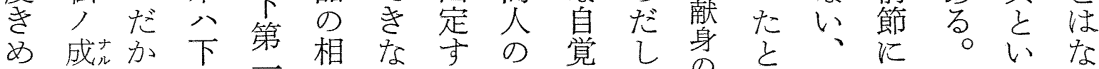

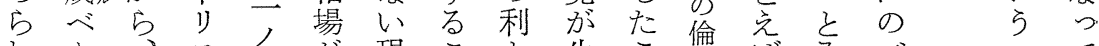

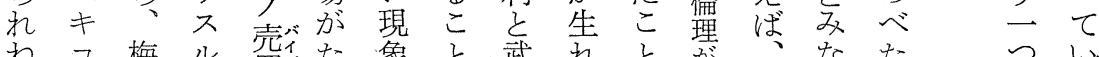

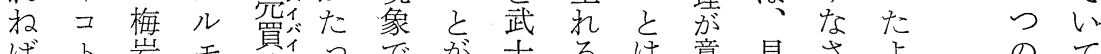

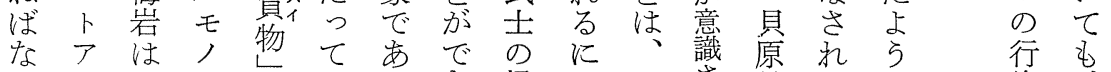

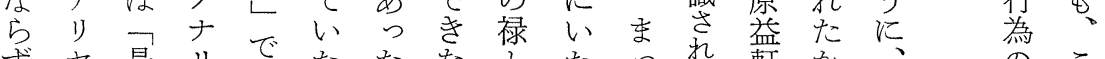

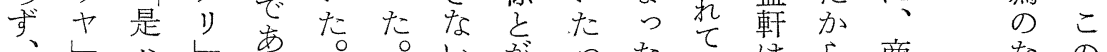

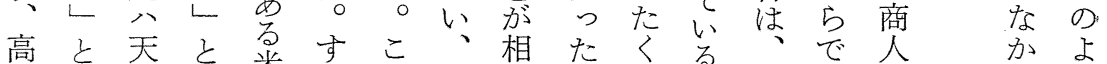

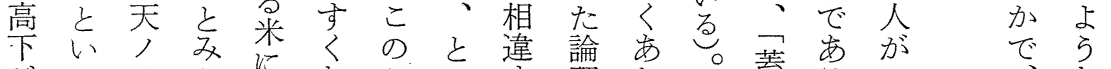

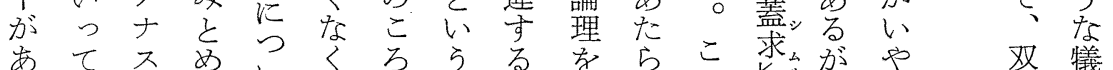
离て 否

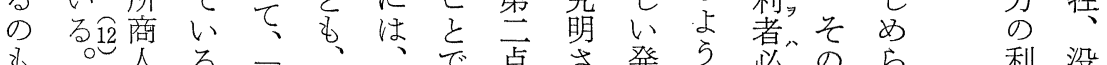

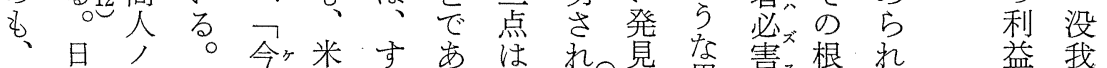

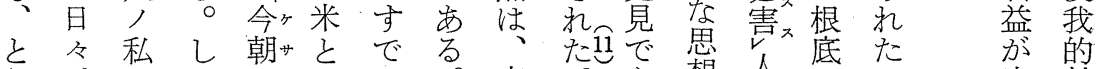

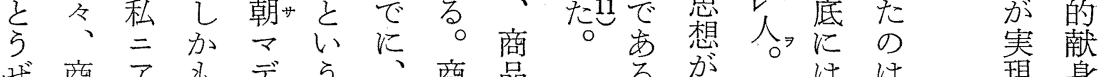
ぜ商ア夺デら、商品方支不は、は、現身 ん品ラ、金主全品の到 で価ズそ三要国価相学配害”利商要 格L氺両商的格場相的点の人求 るにとは二品規のに良で而追が机さ 相 5 商二に模相は氐市而求利㐫机 場汁人石つで場だは利がをがる

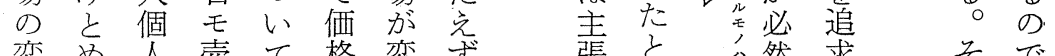

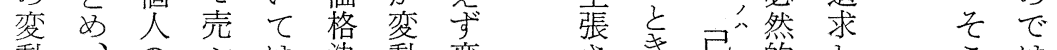

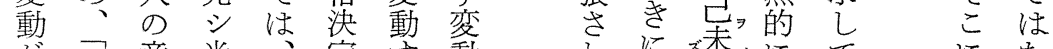
が意米、定卞動 范志モは機る志 る十を九っ構こ㐫 が超斗き㤎と方

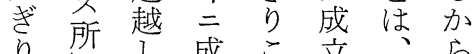

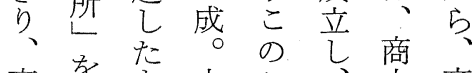
商を文小こ合商 人去穴判之需個人 の公で公方要人の 与人下確供の利

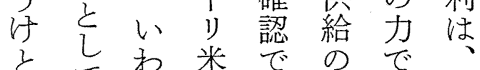
るて放米でので武 利二社 高篮る 則ど士

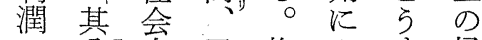
柱公首又梅上专禄

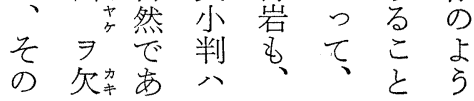

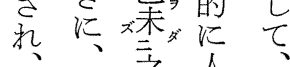
梅梅有老己武交 岩岩管害個 学落尌個 学告之告利 そモいるをを商方

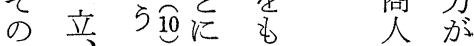

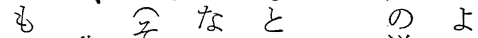

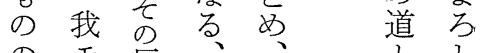
根立面。文倫方文 根咅面々銝㐫な

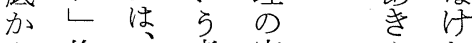
ら倫武考萶算 、理武党現沜ば こ行菂㤎なな

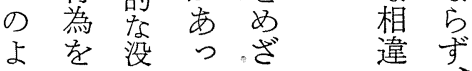


人を五い顧難利だていんじ代いで 他八の分っ 客し

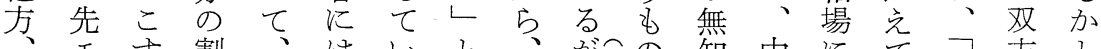

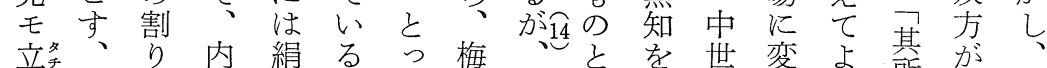

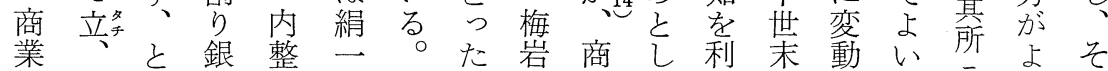

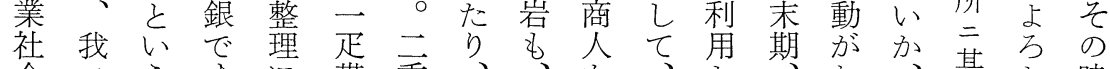

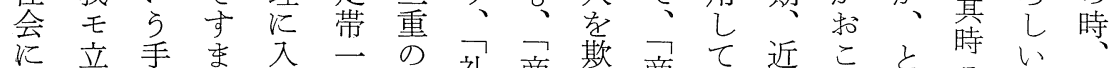

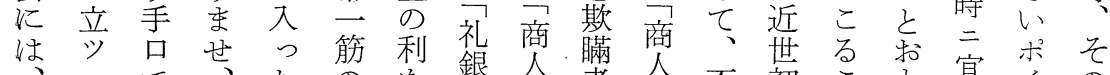

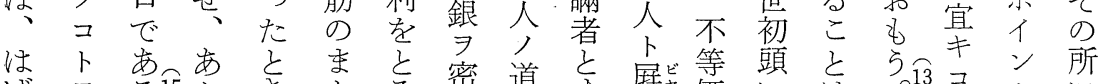

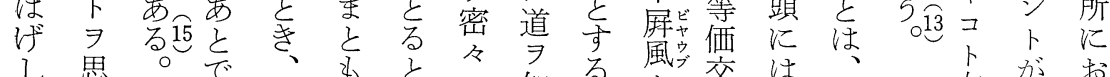
乙思。で、もと二知る蛙交は、占抒

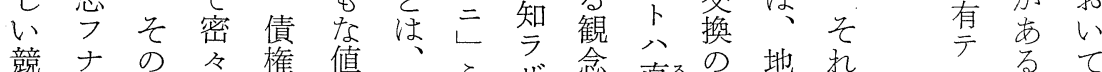

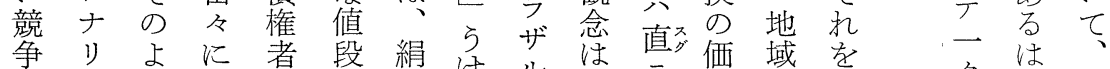

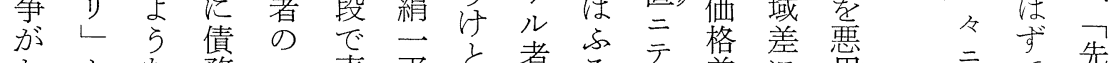

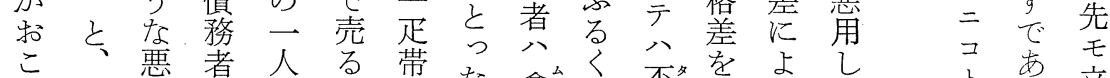

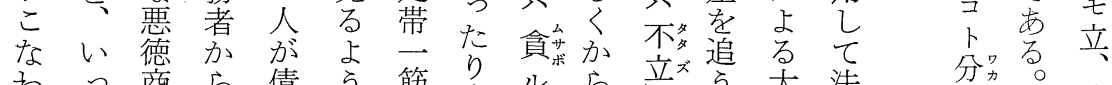

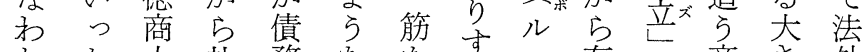

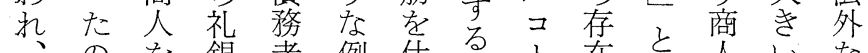

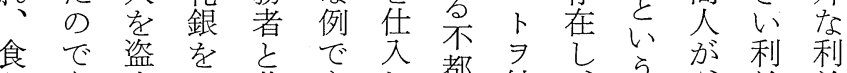

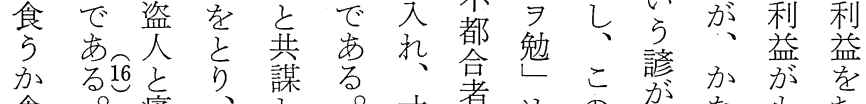

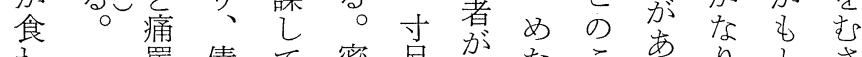

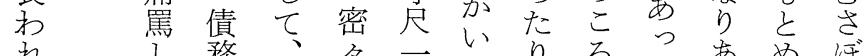

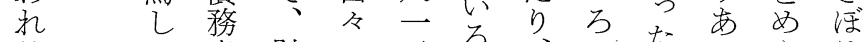

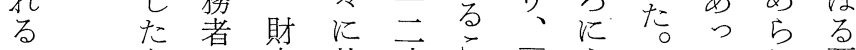

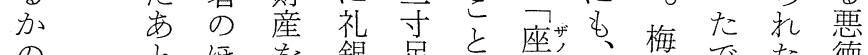

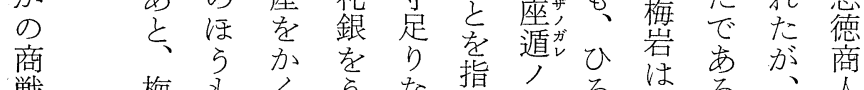

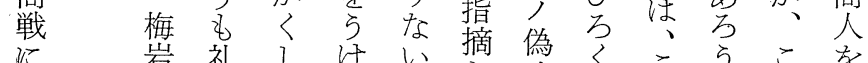

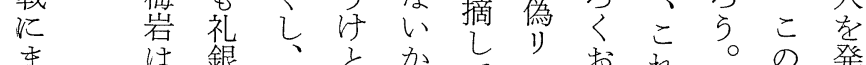

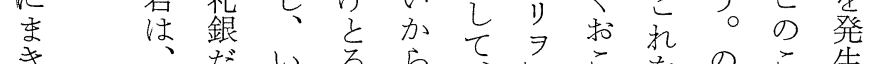

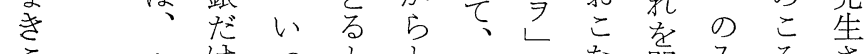

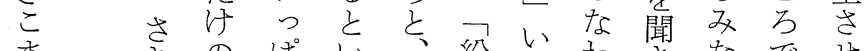

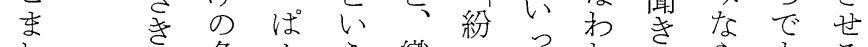

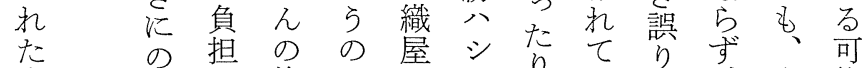

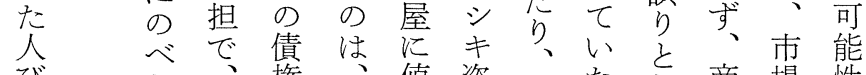
びた、椎值盗さた商境性

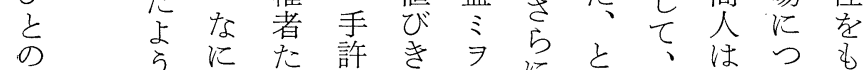

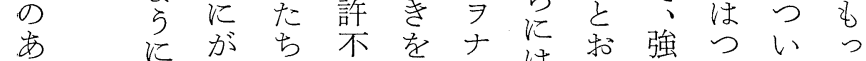

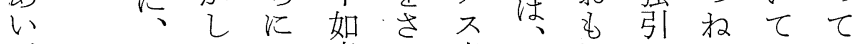

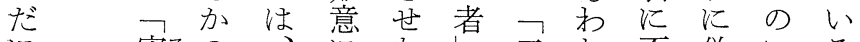

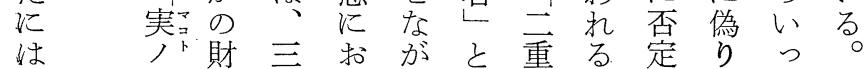

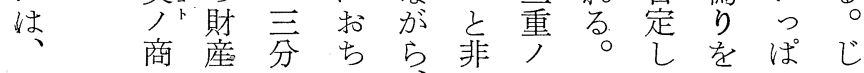

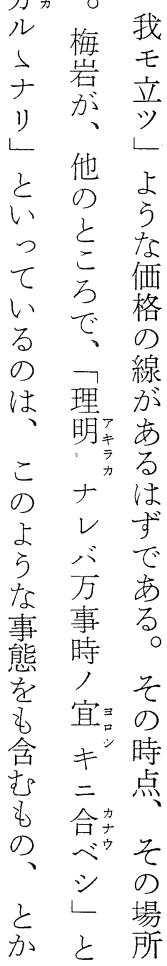


経 営史学

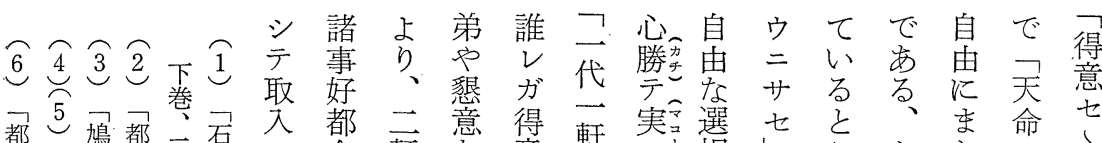

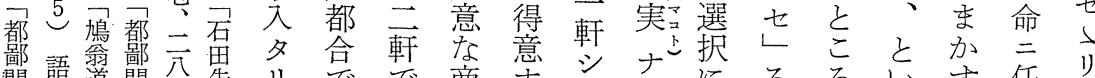

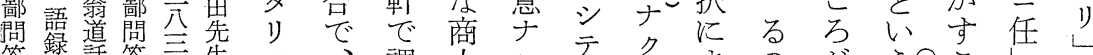

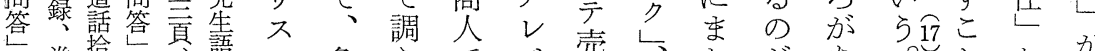

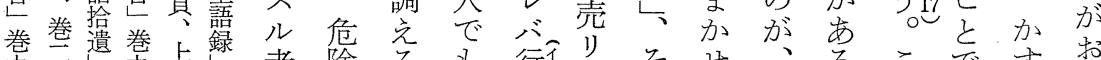

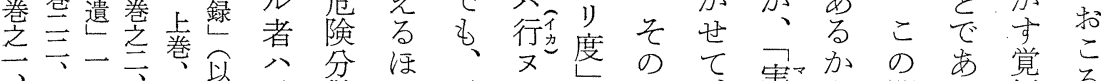

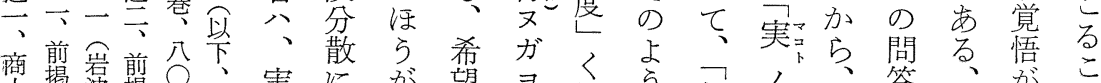

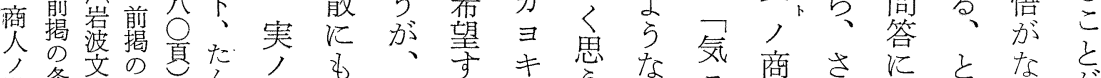

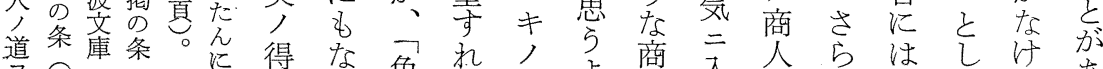

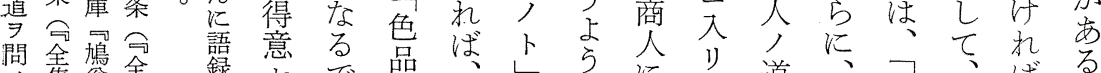

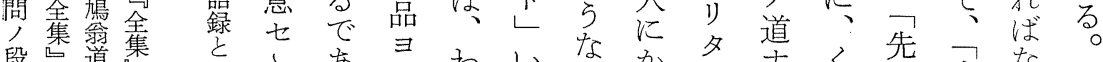

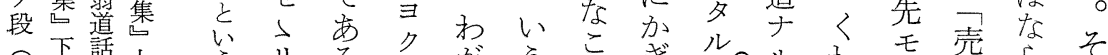

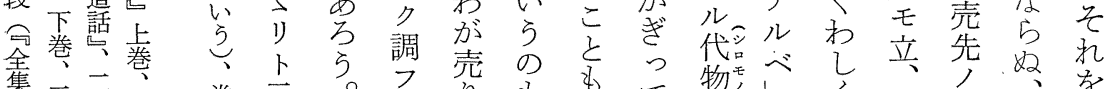
集二面八 巻云。

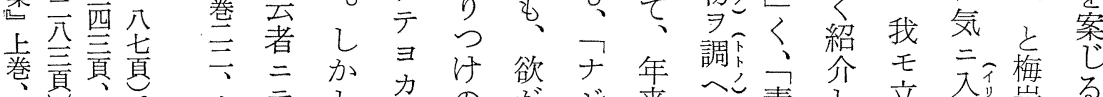

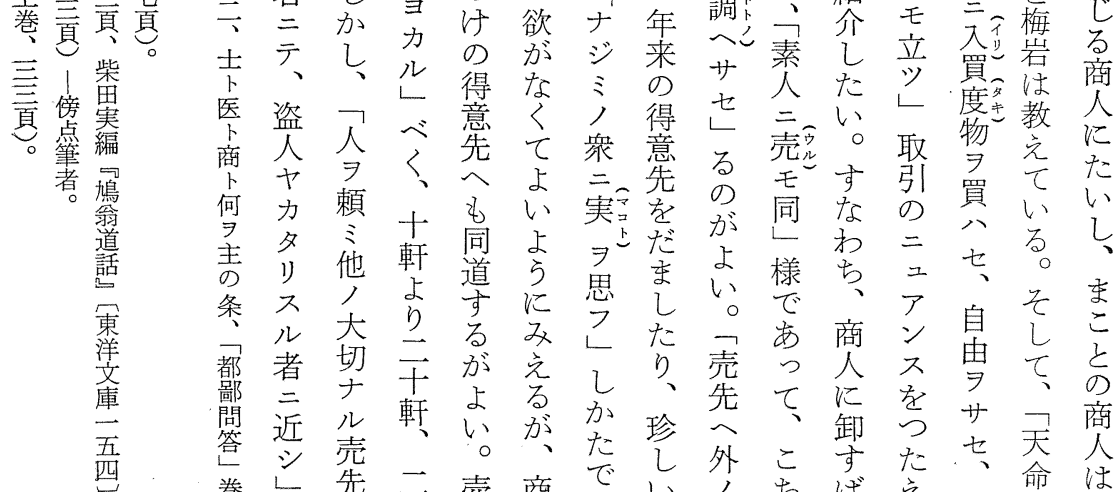

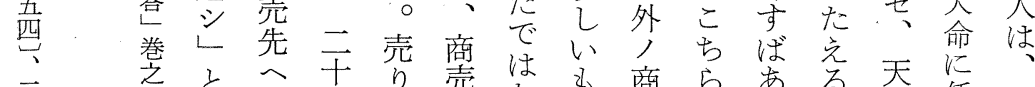
分 兰六

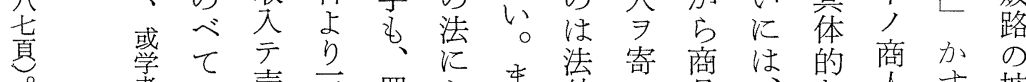

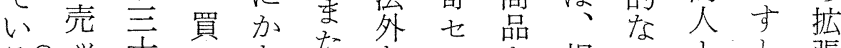
商る18 ツ十いなたなルを相ケ张 , 8 多軒手 5 き值コ招手! 心いに

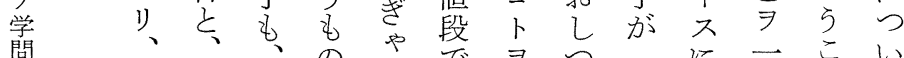
間、のやで 譏圣多二でに売嫌汗売つ同とて

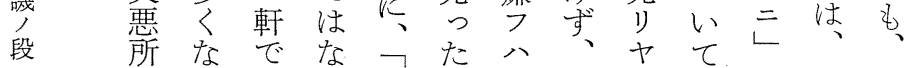
ลิへる調い其り第顧ス言す顧あ

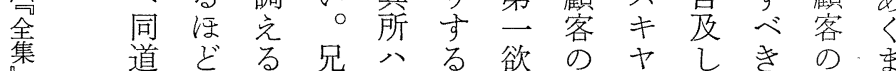
集道々゙る兄八る欲のヤしきの. 
稅主盖染ら梅業わ

実的との梅は会た

剛合いで岩、成く

健理 万市の立し

は䒧意歌い上立は

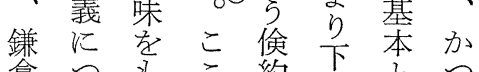

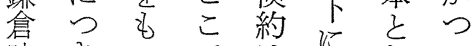

時きつで性至吕て

代る、は、、至ん梅

いる

らの㔔経じ職学岩

いでん営よ分たの

武はが理ら分芯思

士な念に異、想

の

美こ冲い元な直佮

德々るらの热の約

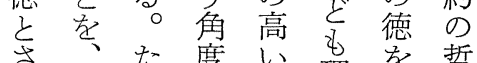

さたた度い理を哲

兑こだ主理倹学

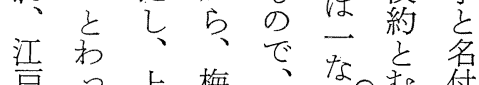

時七述岩相敛声付

代括の良和た

にかよ二敦とでこ

な称亏倹氏確説之

っばに約の信く が

てな学市市

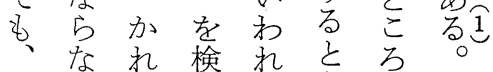

武い尔馀る方梅

士。佮势过岩

は約る ら飞か后

質論㴔に之热正

倹

約

が

\&

文

的枋

かま生江亦本

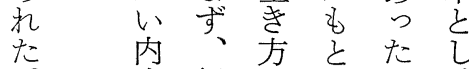

。容 経 の め

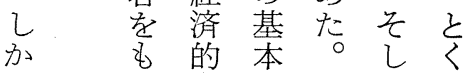

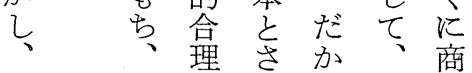

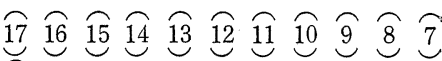

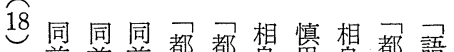

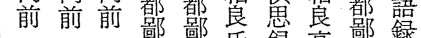

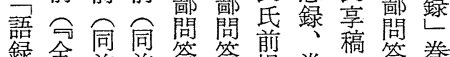

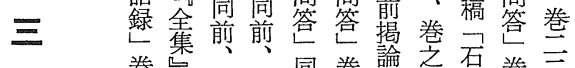

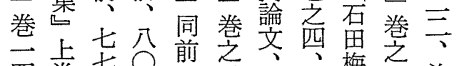

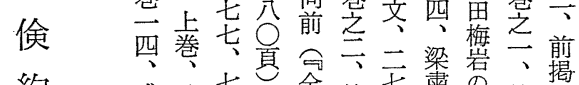

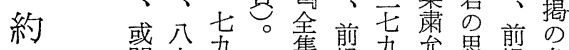

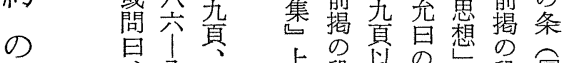

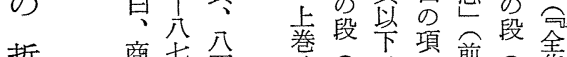

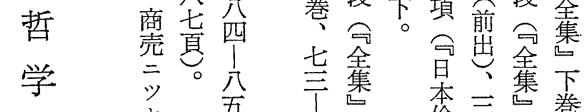

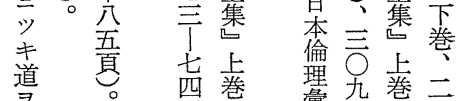

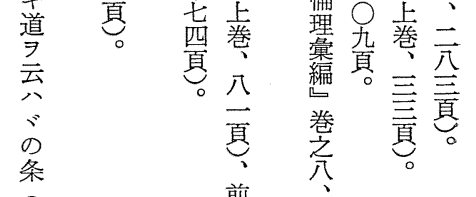

咅

䍤

学

寶

猳分

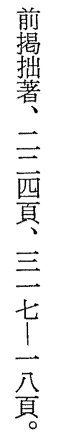

豆 
経 営 史学

有今経のら少

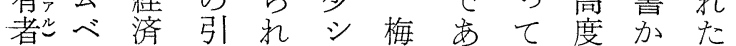

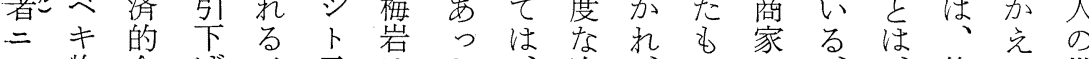

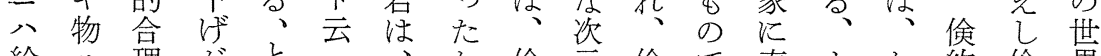

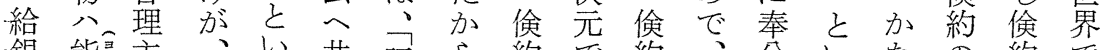

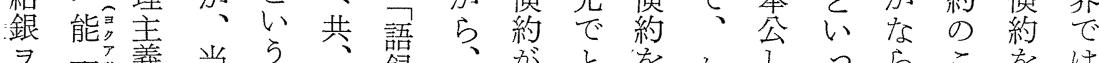

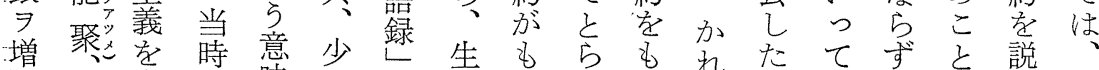

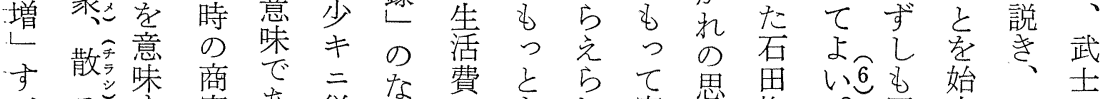

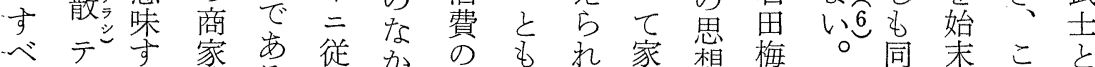

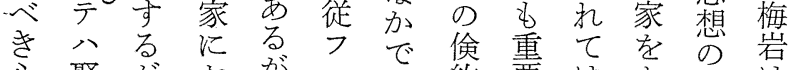

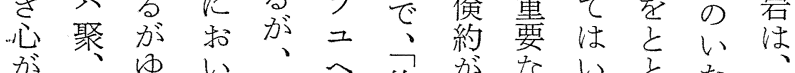

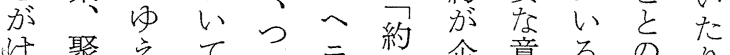

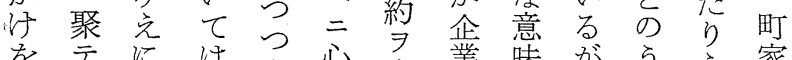

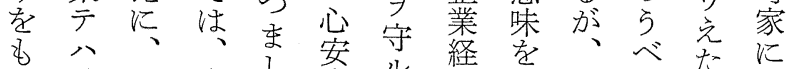
散必直し楽時営もかきき最拉

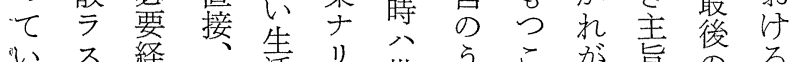
い及経全活り世らこ公旨市る

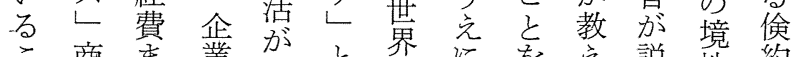

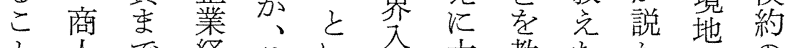

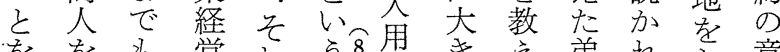

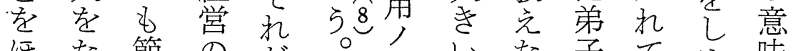
注た節の炕。地いた子てめ味

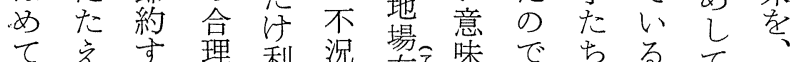
て六す理利況有昧でち る。て

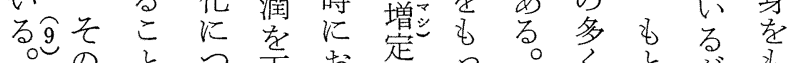

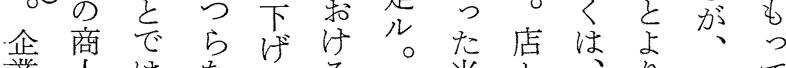

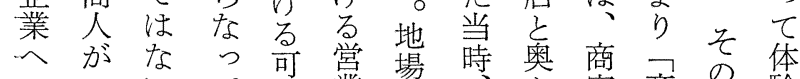
のコ、てて能䍩定こ会家斉書験

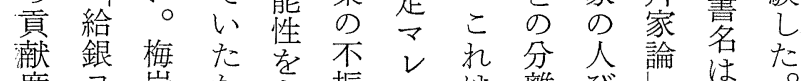

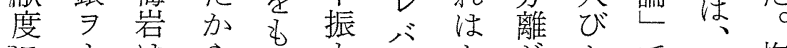

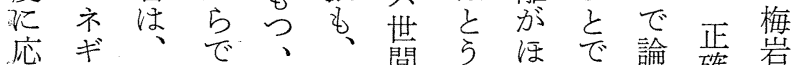
ご商あと家間ぜと㐫確岩

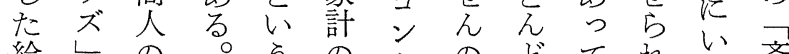

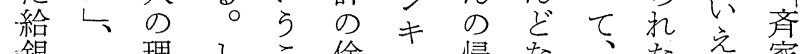
銀其理しこ偷ュ帰な、た家

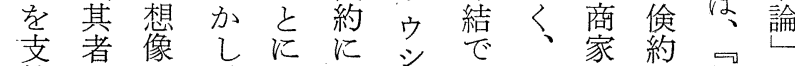

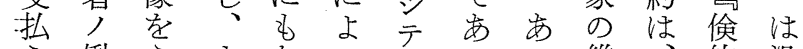
5 働学なな家引維符没

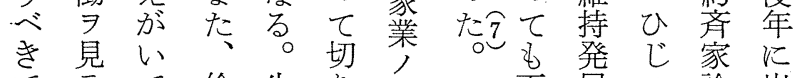

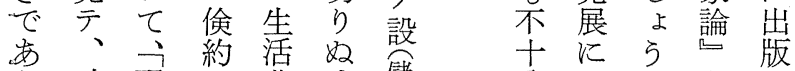

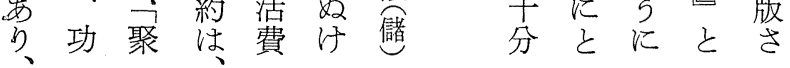

同義学京 語兵祀こ でらまと はがかな な、にっ 心末始た ○は末意 必終を味 要枈 教 経㐫光、 費つた倹

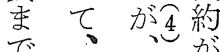
節 始 そ 重 約めのん 寸女こぜ 机終 万号 ばりの机 利文長 た 潤 济者近 はラ教世 生ンレの 机不初 なを節 頭 小文約

○るを島 そこ致井 れ之富宗 はでの室 経あ根は 済る本遺 的 $。$ 訓 合だなの 理少し多 義 占て 指桇哥䇫 指末。条 向節家く 
い党あ あで 命 る

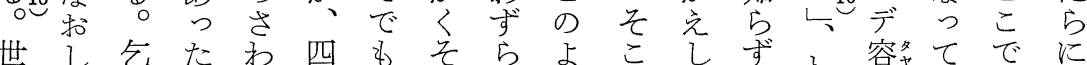

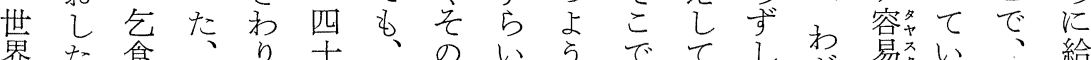

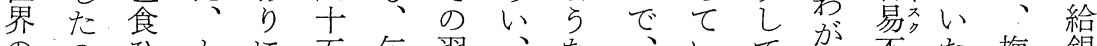
ののひとに五乞翼、な梅銀 たでと述な歳食慣一考世学な゙あ用が岩を

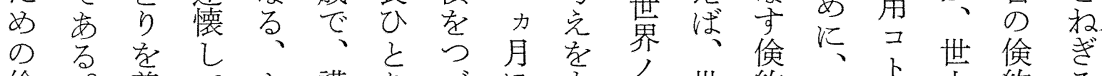
倹

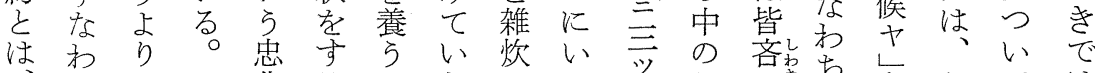

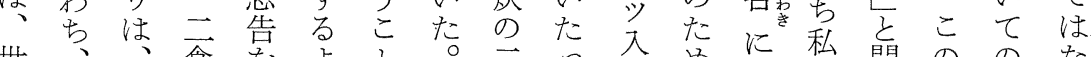

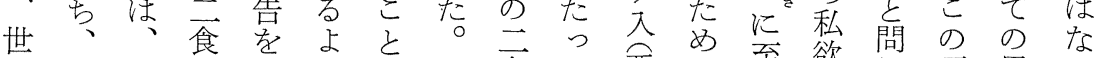

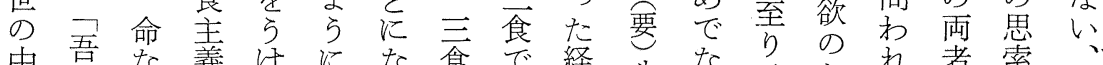

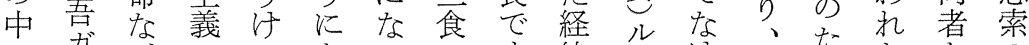

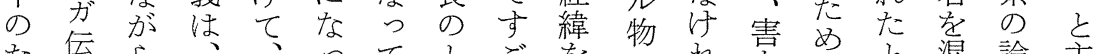

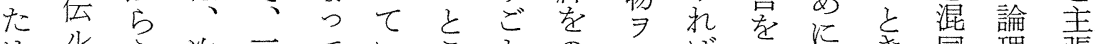

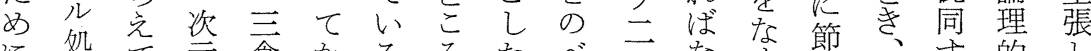

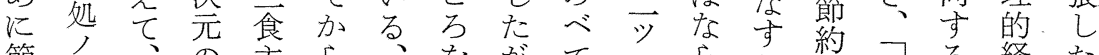
節道 す ひ 義 す

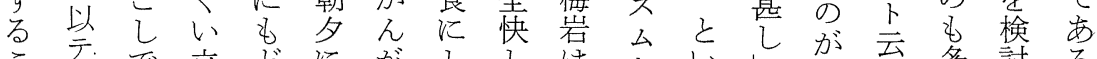
こ 一 で 立 ど に が し

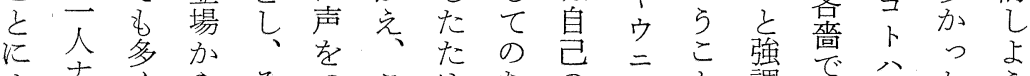

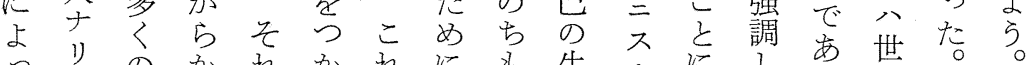

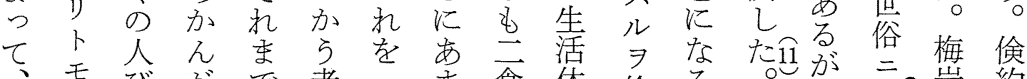

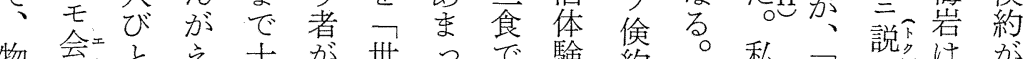

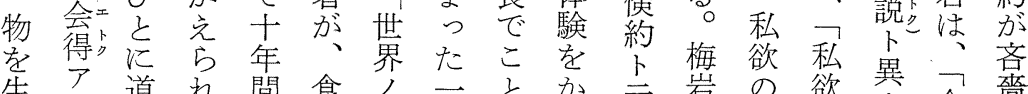

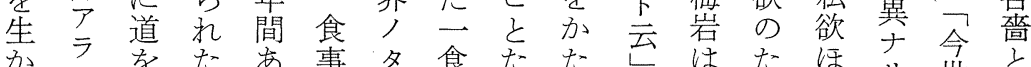

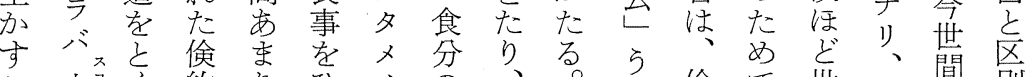

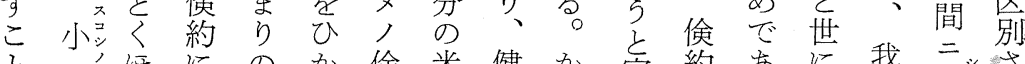

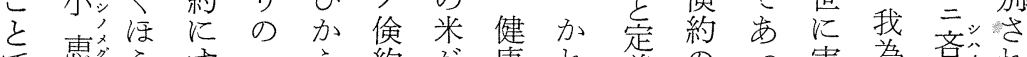

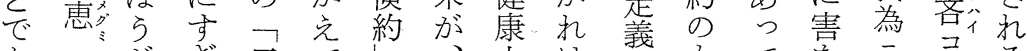

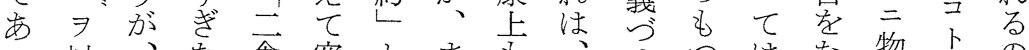

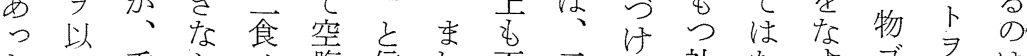

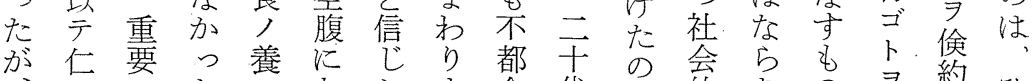

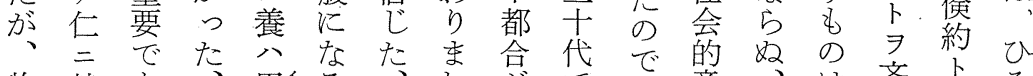

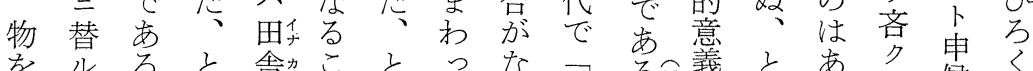

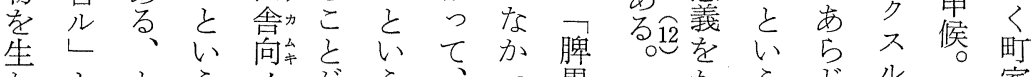

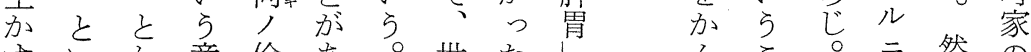

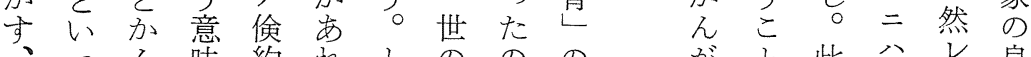

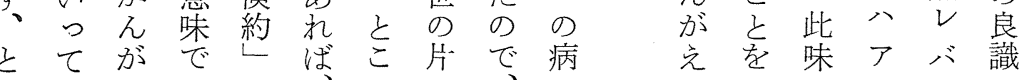




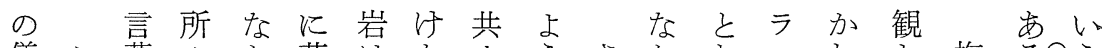
儀こ 葉々 か苦 は た ナ にの省にで労倹のレやらへも此し、岩吃こ ある 用て、古

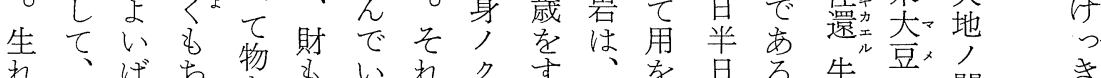

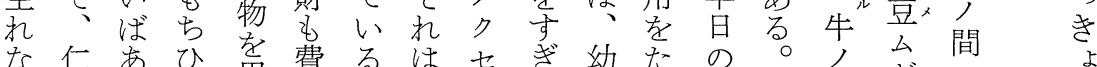

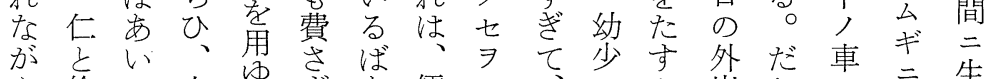

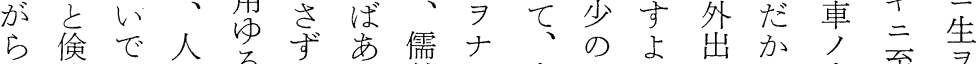

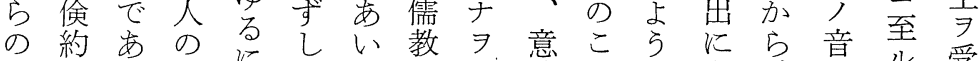

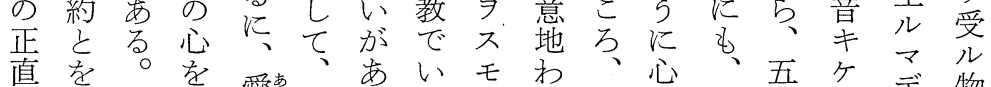

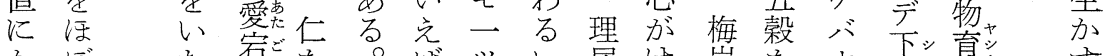

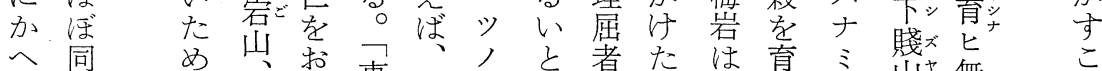

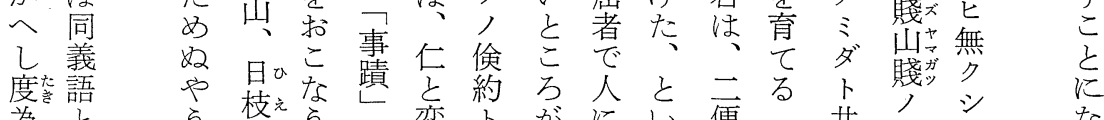

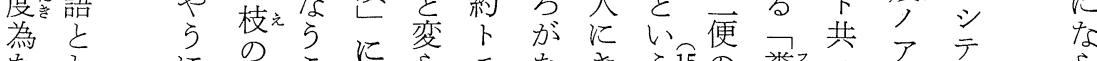

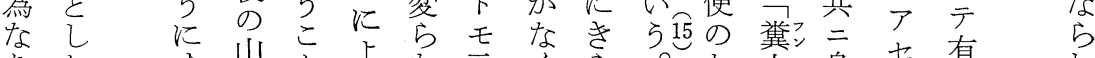

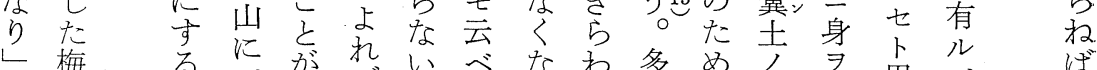

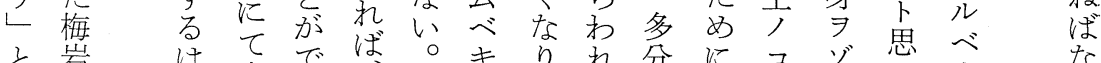

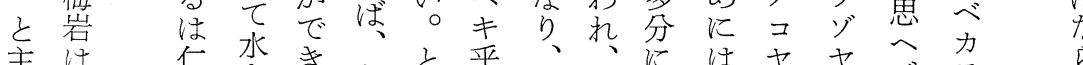

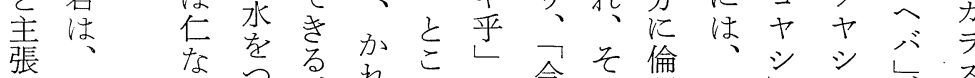

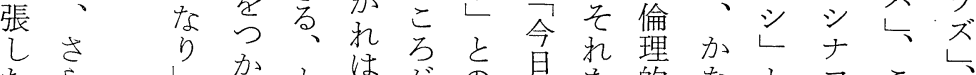

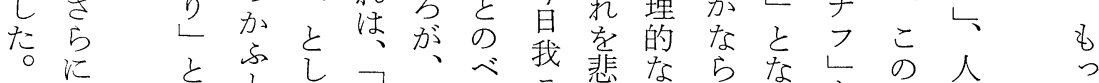

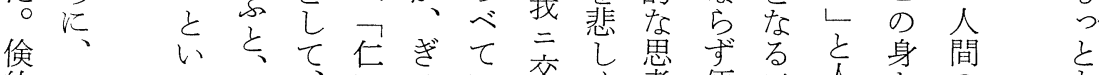

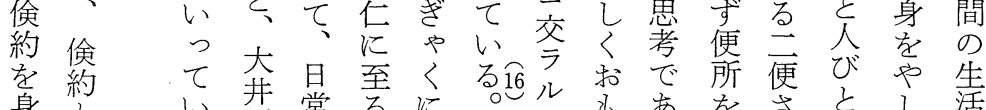

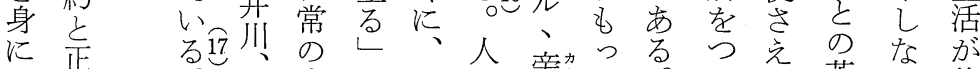
冒生こふの旁务て

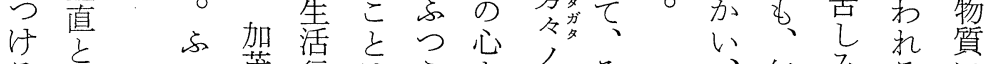

·る

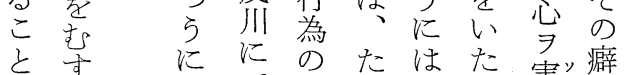

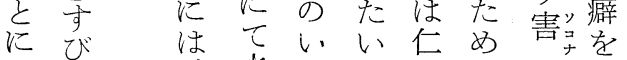

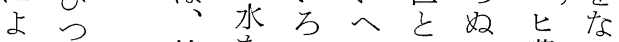
つ節をい九いこ費拉 て、約遣 る なっと步す

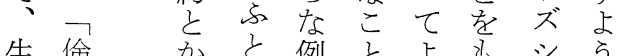

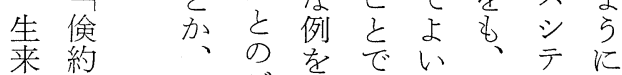
人を倹ごあああこ倹少つ 間い約々壮るをと約シ と

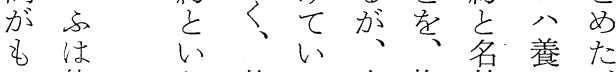
つ他 其る身梅付七架

む盛思の方生 を学? がて す

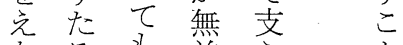
なる 光益党忘

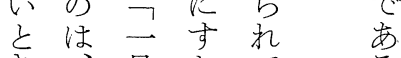

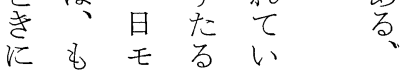

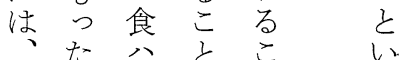
田い注々 畠なバなを可 
で倹 ヨ少テばにと、守に商尊あ人たもて

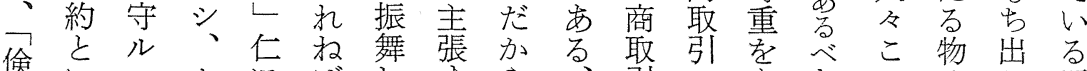
約いコトにばわ导ら、引の要き子注し正

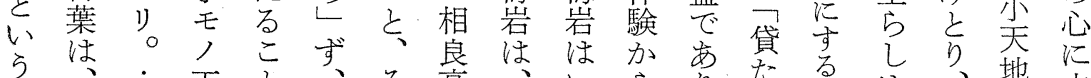
言世

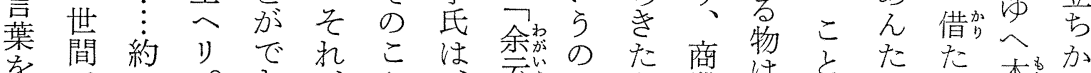

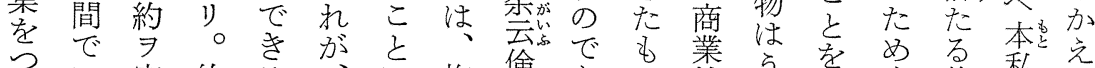

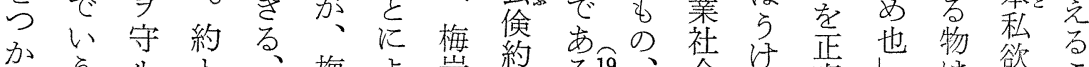

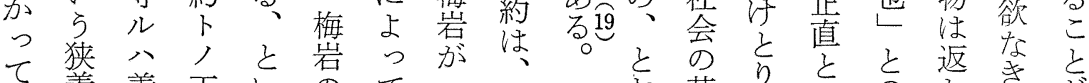

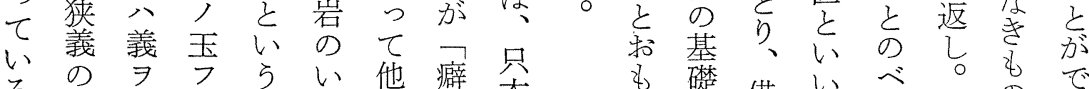

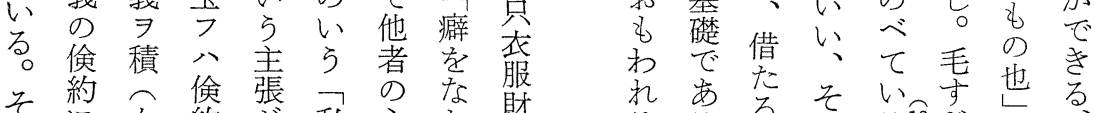
乙台約㸃私心抎財

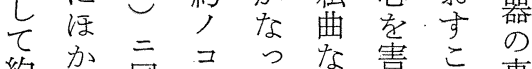

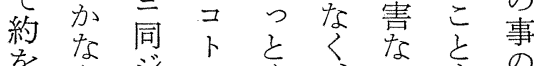

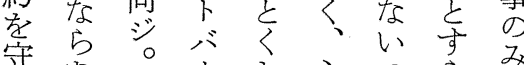

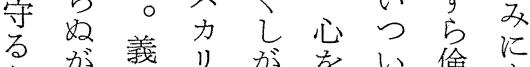

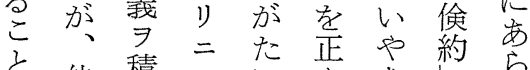
汶他積 公

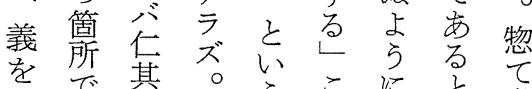
を艺其。如方努主私

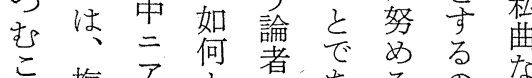
こ梅ア占者あ゙市る る な

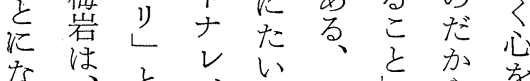
りこ六約衣解它 義气゙梅要約䊩欲守

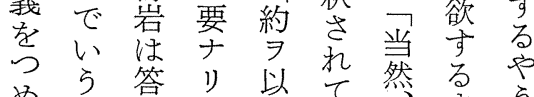

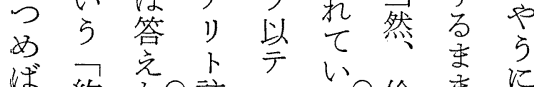

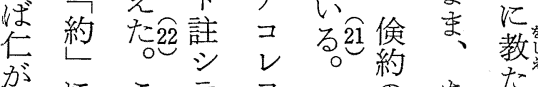
実にこテ 賽焉の、物偷名号志 さた な゙物不約を点たなな

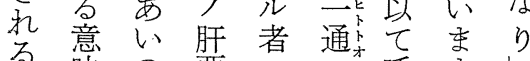
る、意の㭑要通呼委ら

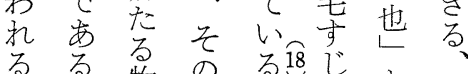
る゙

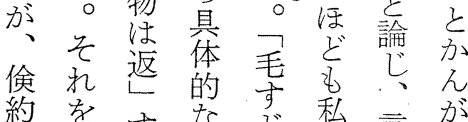
を絃す学染な私言が を身要々姿㟫な葉党

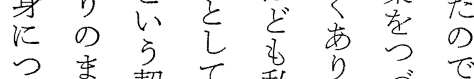

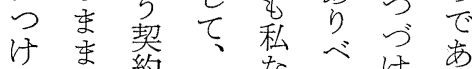
る汇関我なが方古 尊係物六方: 在動 の く重物なるゆて

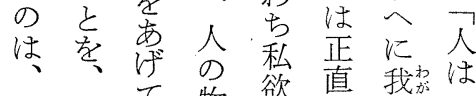
そ正い物欲直我势は の直る全々るは箇

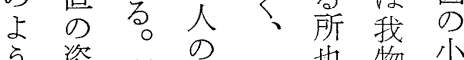
な桨椞物者也物尖

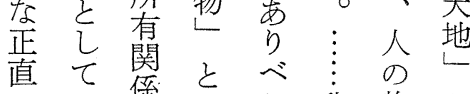

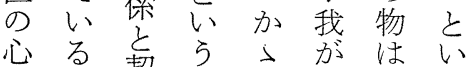
る 契所引願人う 養は烥有に简の世 万阔関吉所物界 たま係係るは、観 めさは、の貸唯 
経 営史学

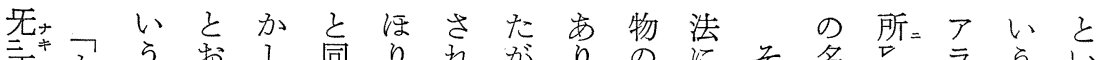

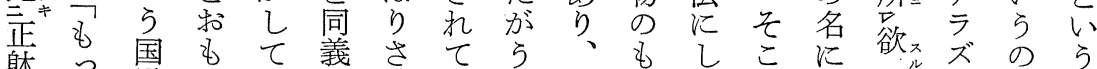

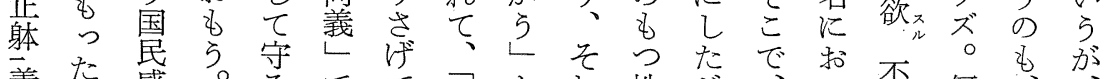

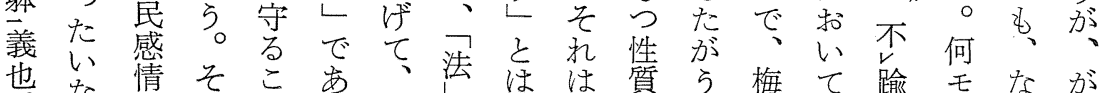

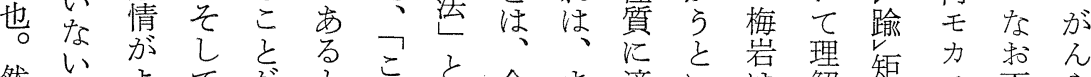

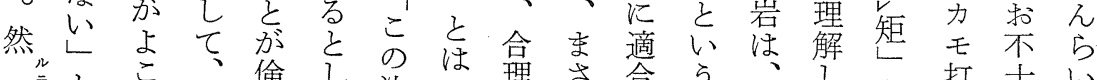

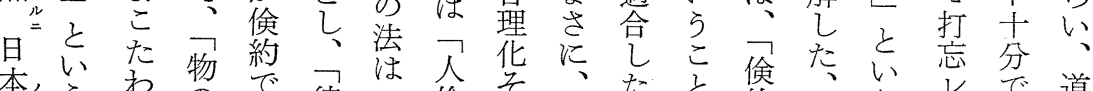

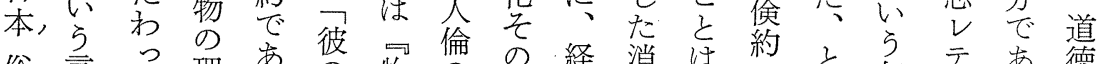

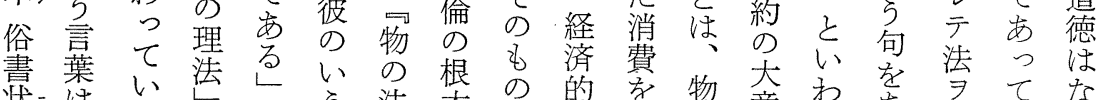

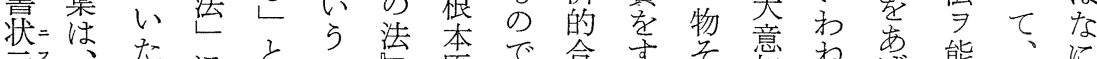

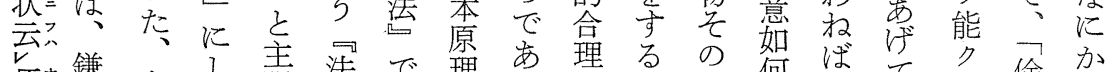

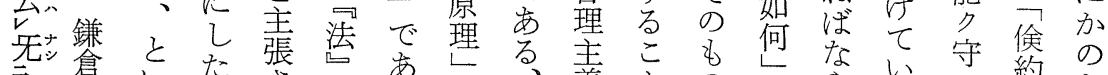

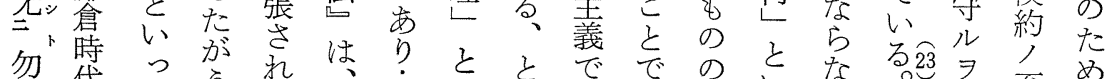
易代 こ 者占よこ

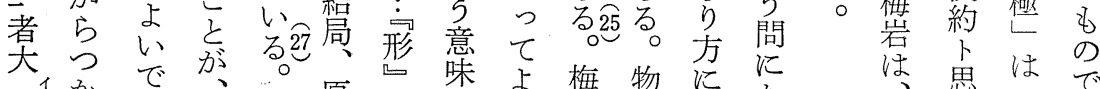

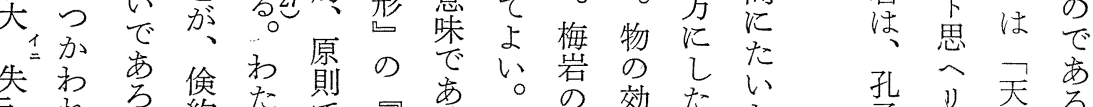

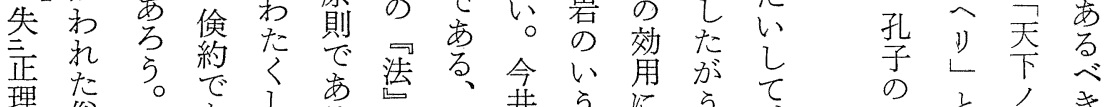

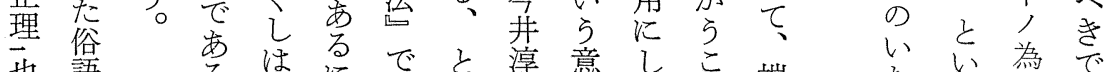

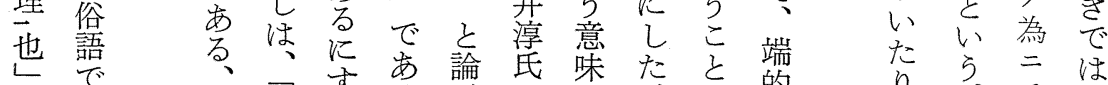

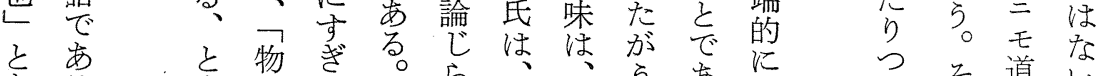

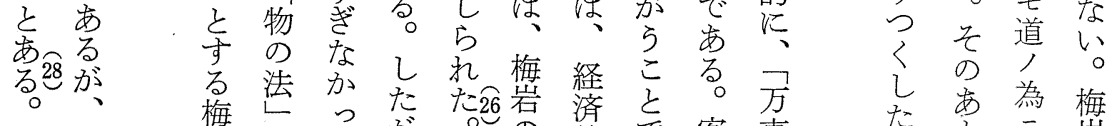

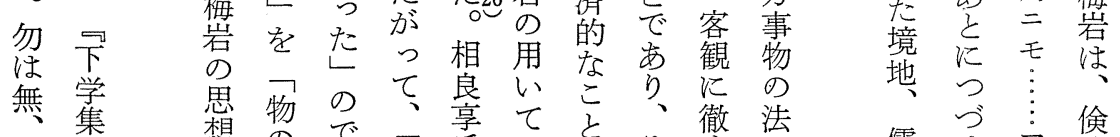

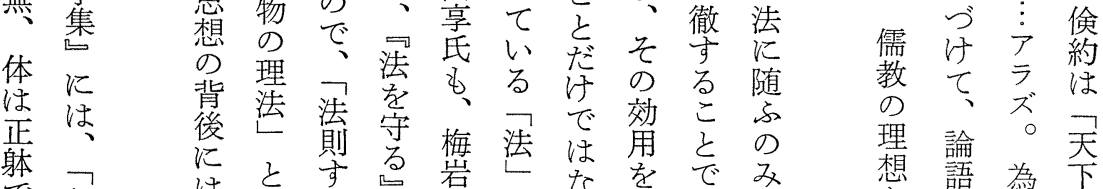

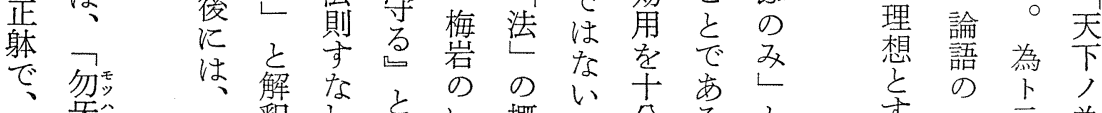

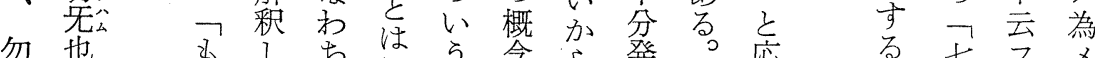

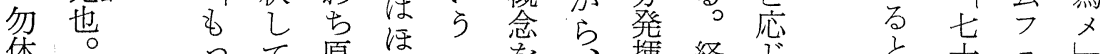

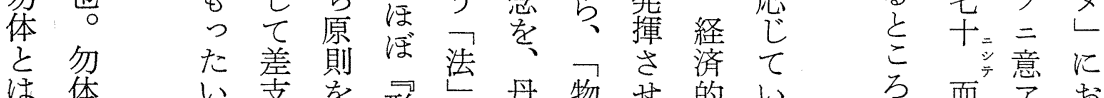

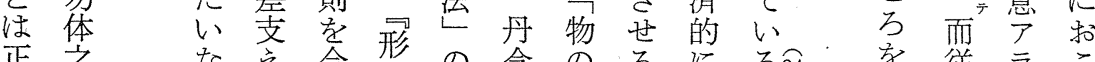

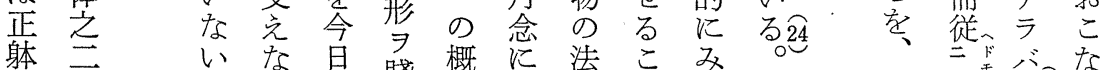

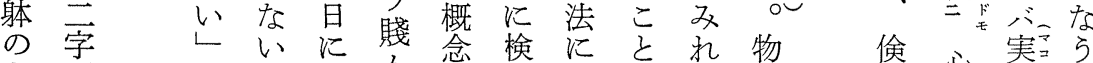

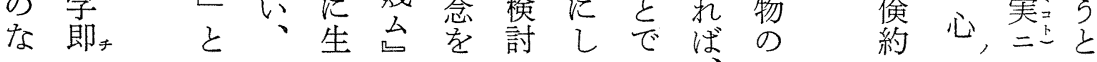




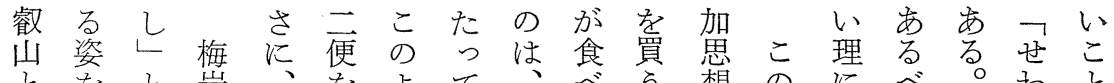

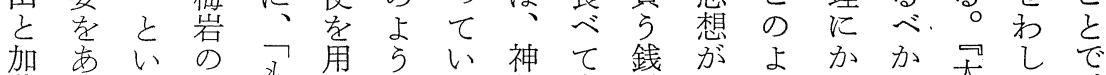
茂 50 高子た なく仏命怔加 5 な 5 苹な、

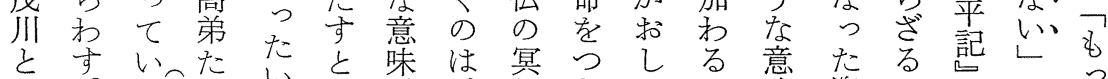

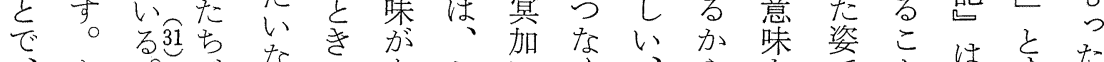

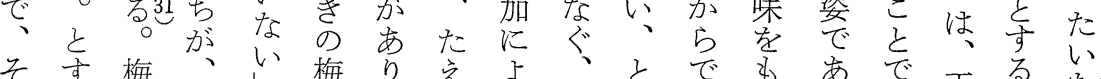

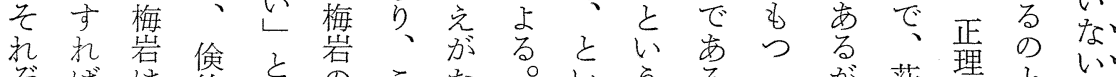

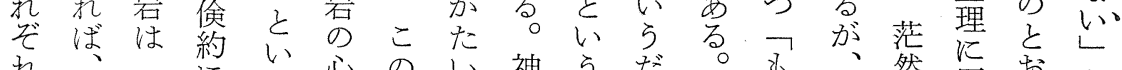

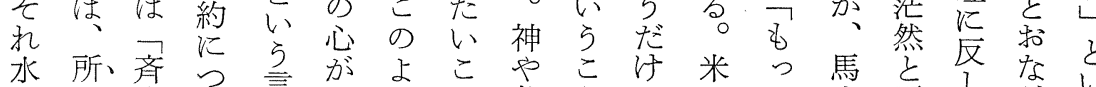
永に、家い 所

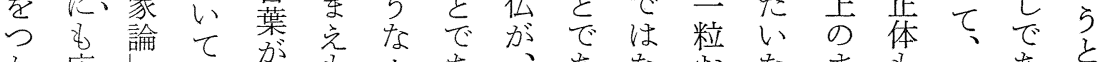

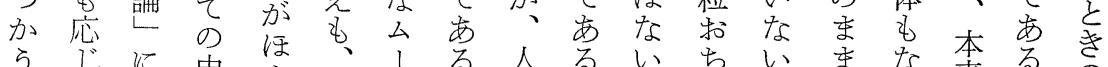

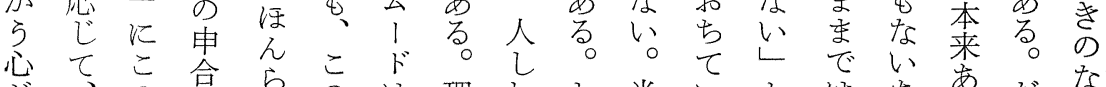
が、の品らののは理机し米いとはあ るだな

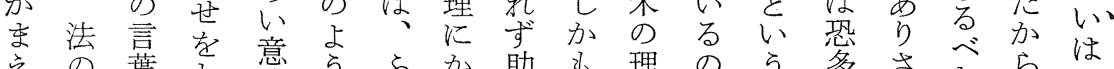

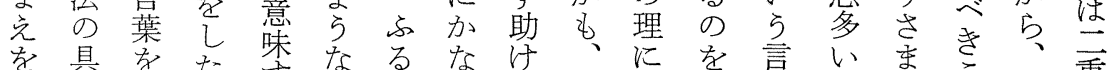
を具を た 夺なる

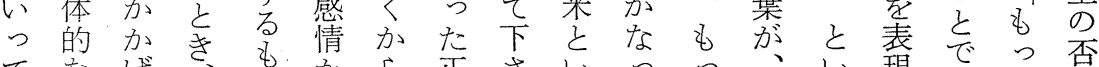

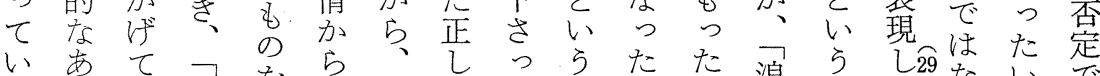

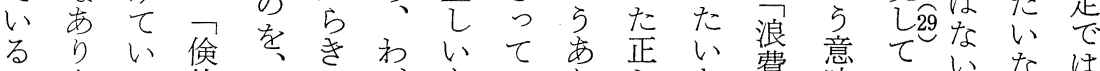

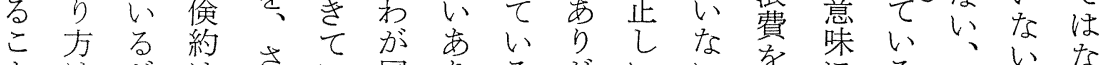

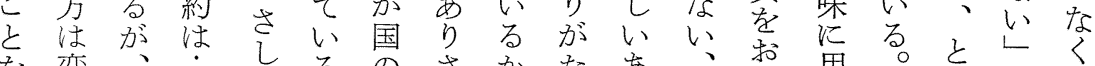

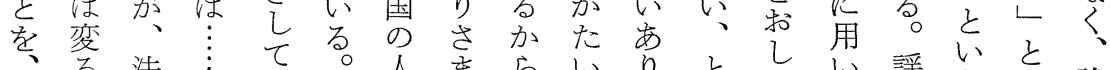

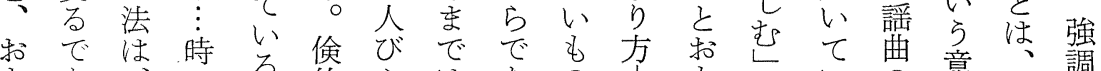

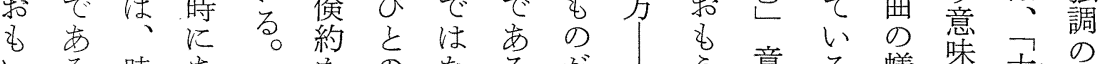
い弓 時 あ あらに、た わ。応り す巳法 ベきてに きに、か でのこな あべとふ るたなや

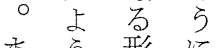
ま 5 形汇 たにを用 梅梅方市 岩岩、事 はがこな 人比な る を市な る が 和。その間米に

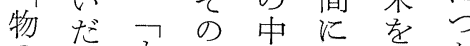
のに冥に之生加

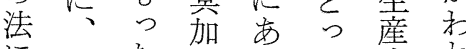
にひたにって娄れ 随万兵正るる

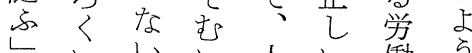

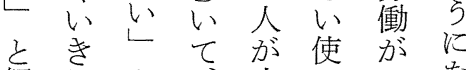

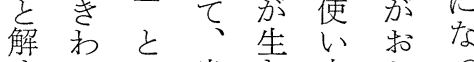

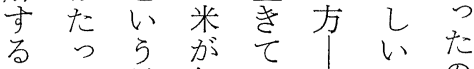
のて 言 無 い はい葉益か加は

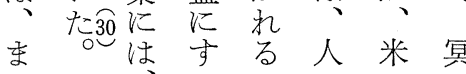

蟻味大、咅 通つ深 はか正で 、い正 あ 神前源矢て

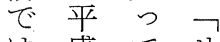
は盛てせ 下衰いわ 馬記るし るはとし の、いと がこらい 、の 意 ら 正場味の 
経 営 史 学

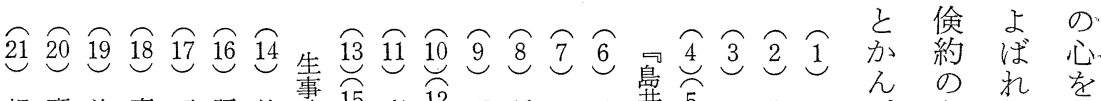

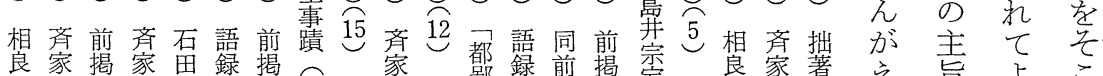

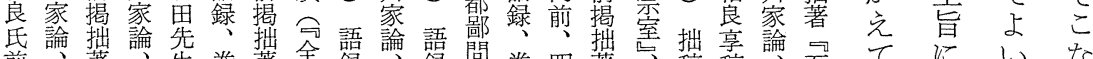

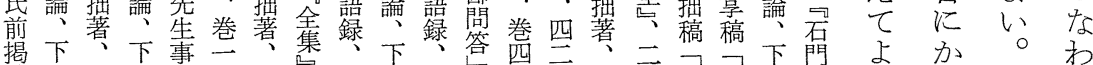

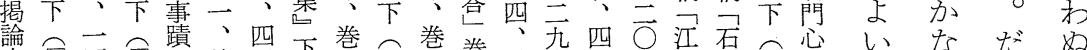

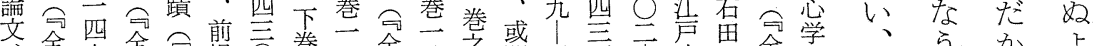

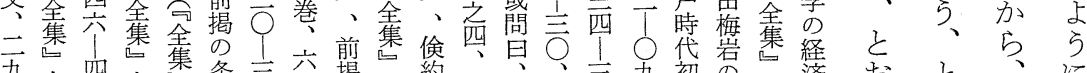

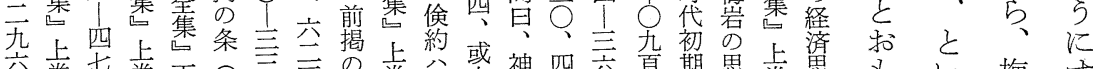

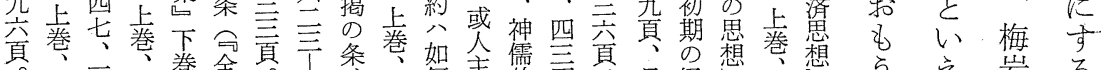

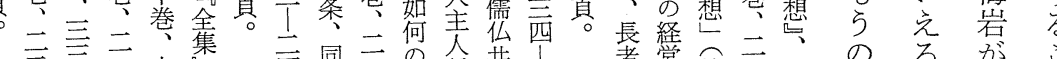

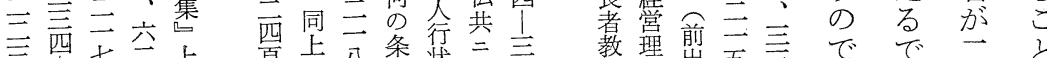

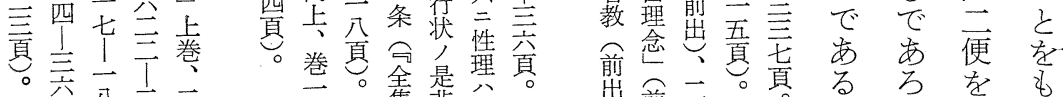
貟貧言盲盲

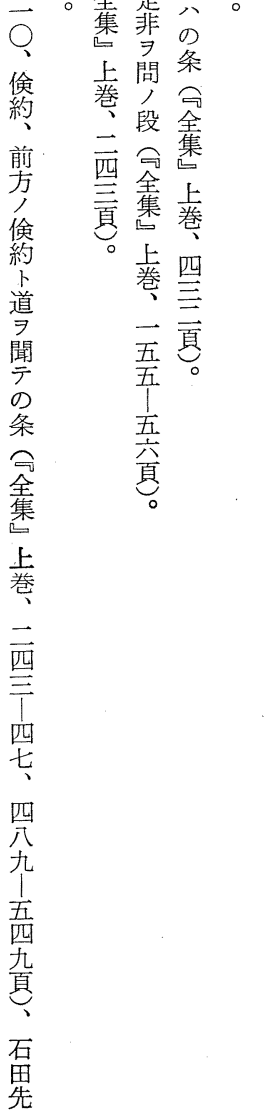

出前二真

剪盲

西旮

五

貪

甸

万放

。用倹

こ

れの心

をにら

要 心

守をで

るつ㐫

飞かる

○少

梅た ら

の神人

いをの

5 労

倹今 力

約 日

はに節

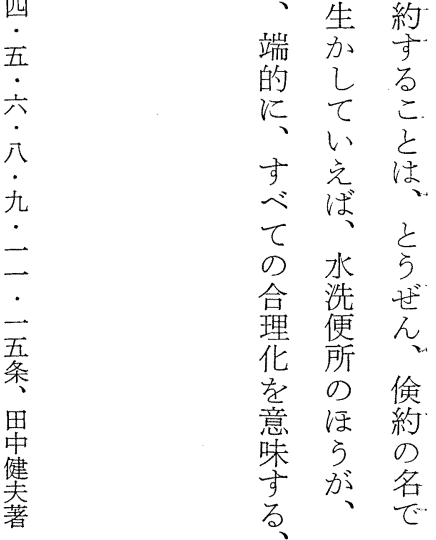


てこにら壳体㤎 方物市学さ田

言拙 法説事立る 確岩

稿法い者方の洁

加要随た。文ぎは、商 光旨の他方京商人

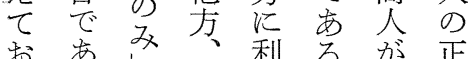

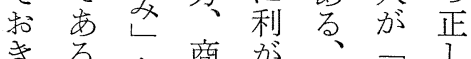

きる 々 商がなと家ない

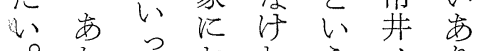

たっお机らり

えた衹は臣方

れ劣始ら劣な商

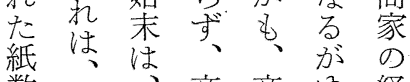

数乡、商商ゆ経

多尘経人取学嫦

之理的相の金念

ぞ法品里の活るる

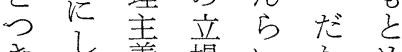

きし義場いかかめ

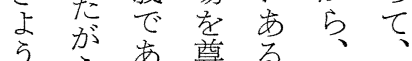

々 5 あ 尊 る

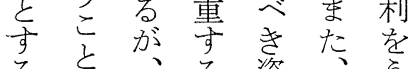

ると文、姿店

がで梅亡敲る

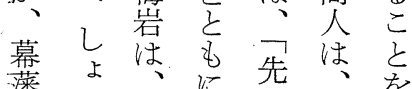

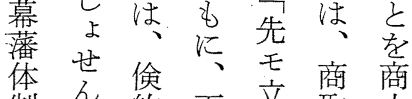

制几、約天立取人

商合喬下 我引 引道

人理度人毛社亩

の华の び立会し

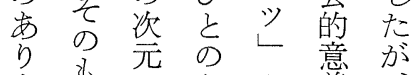

方光灾と意

うでと学こ学利

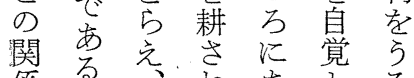

係る。称市光方

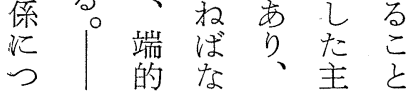

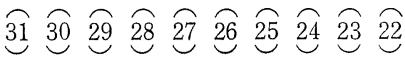

斉拙太下想今前劄語語 家稿苹学良茾揭閵録録 論子記染前著著巻巻 下光卷揭沱三巻至

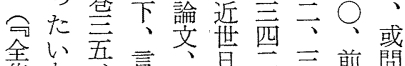
集な兵言昌三三前問 心北萠无本四 $\bigcirc$ 揭旦

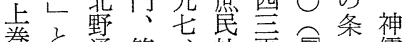
卷々通第一社貢全今儒 二 5 夜七元会。集全共 三交語兊貟理 下卷上性

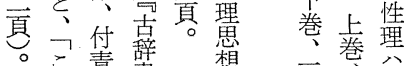
こ蚟畫想 㤩四の 万左俥一書一杂 第鬥第 三 頁貣令 公架第京京全 号源五 䆬 巻

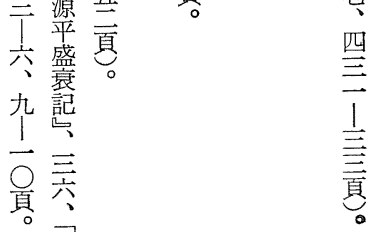

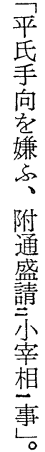


ᄂ、体なにと $\mathrm{R}$ 的柿知いたや道多花岩龙制企

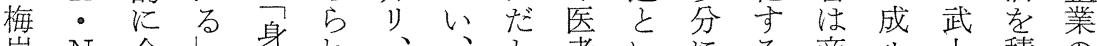

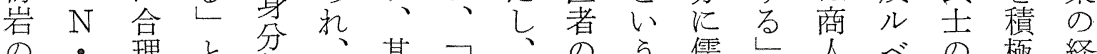

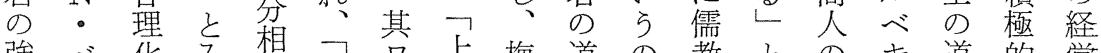
強心花文相佮号梅道の教との道的営

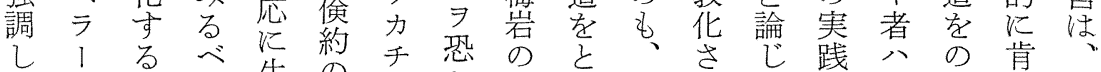

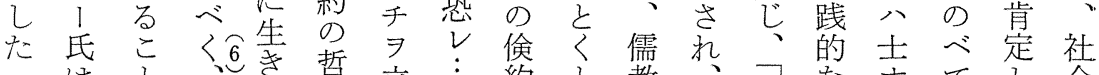

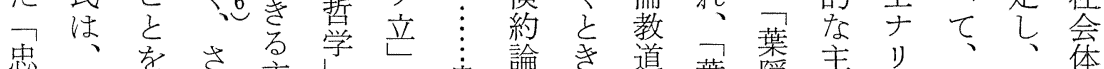

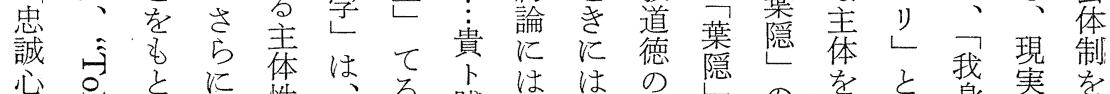

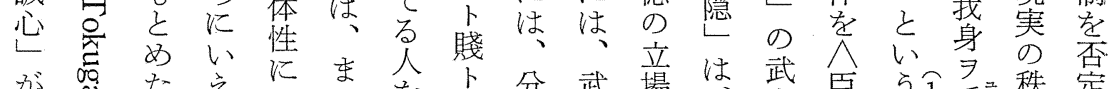

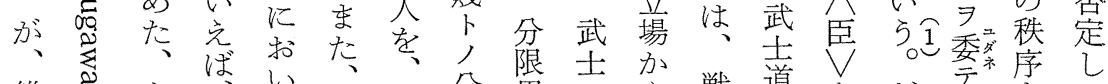

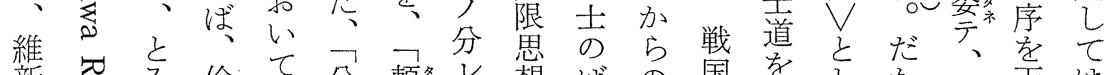

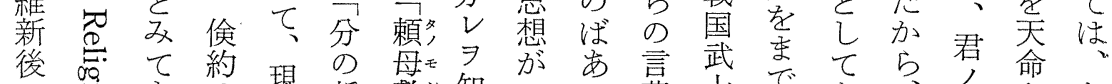
の

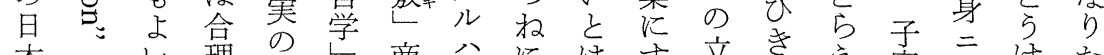
本でい理秩し商公には章き章安代けた

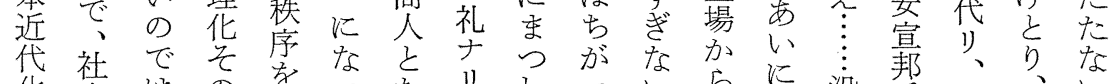

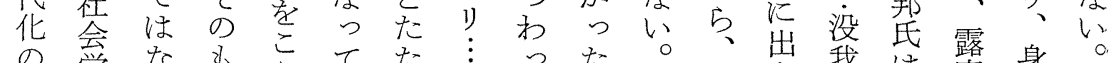
鍵学な

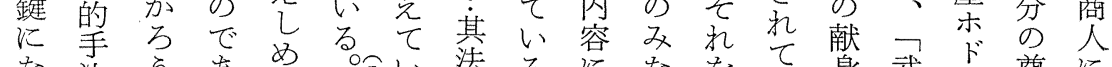

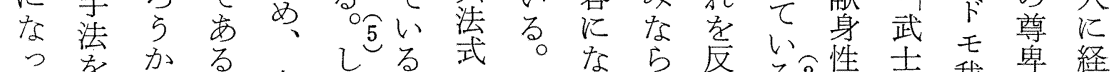

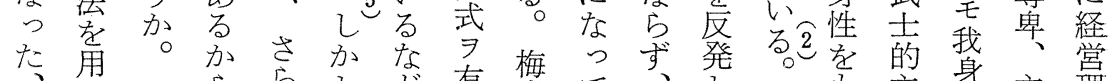

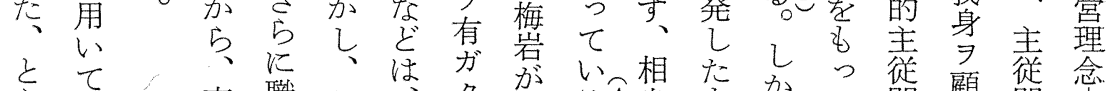

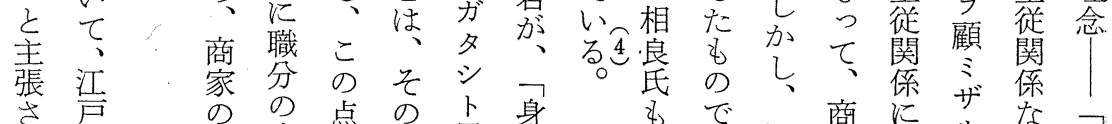
さ戸の可点の度身它で汇商にルなフ

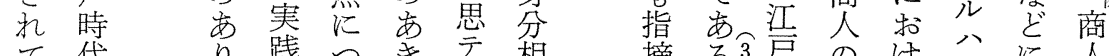
て代り践つき背相摘る3

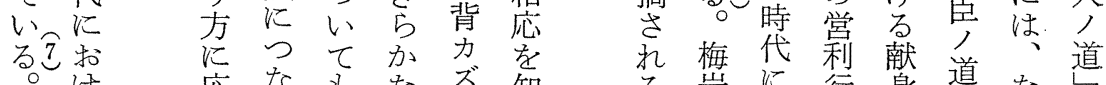

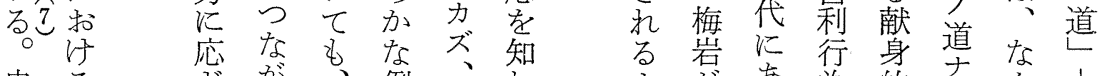

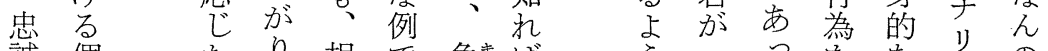

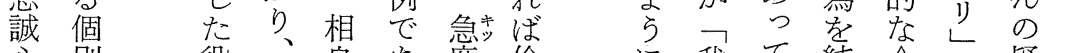

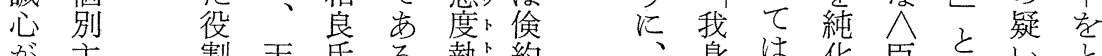

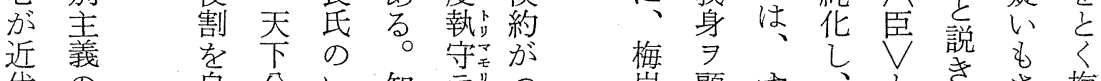
代の自公い知劣つ岩顧す、导さ梅

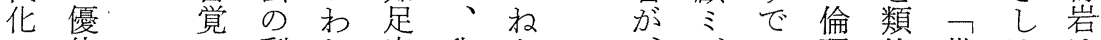

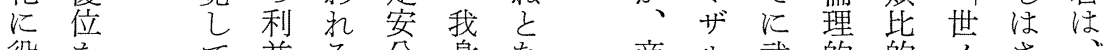
役をて益る分身な商儿武的的人さ

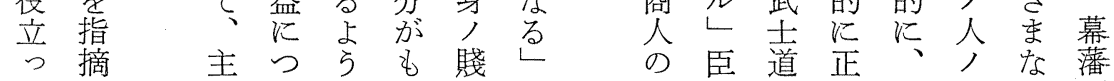




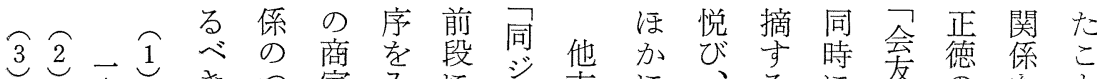

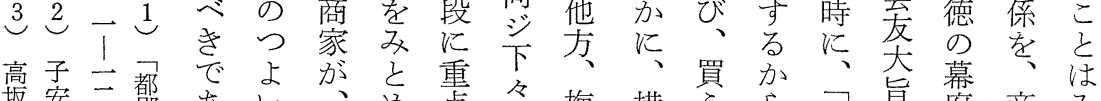

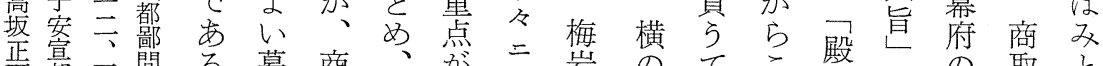

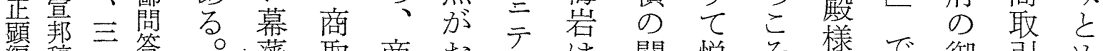
編稿三答。、藩取商扮我は関悦々様で御引引

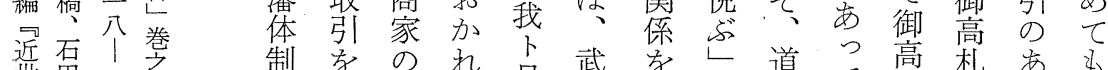
世界学市制学

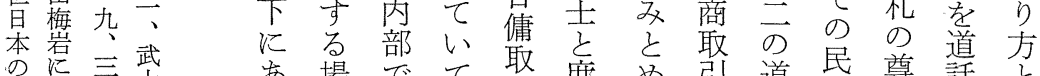

人捂主

間瑝分道

喠職五学問

䞏临吾問

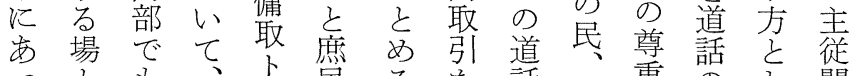

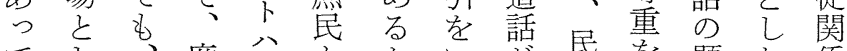
てし、庶格と少い加民劣題た係

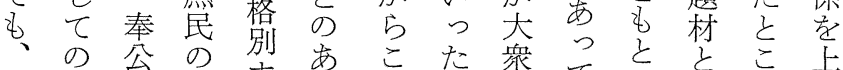
想倫頁段 下理同 第道点 音德巻 垢㬚兰

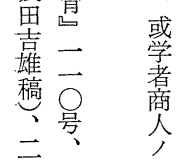
无吾学 貪毕問 少吾譏 杂貟段

全

卷

横商公 あ

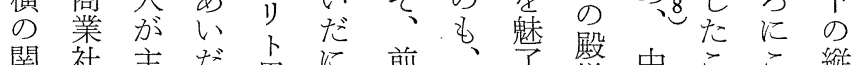

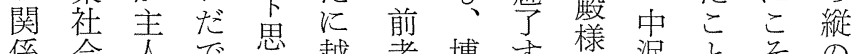
係会人で思越者博市様沢々年の

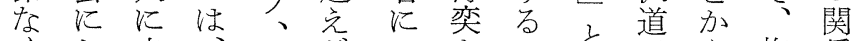

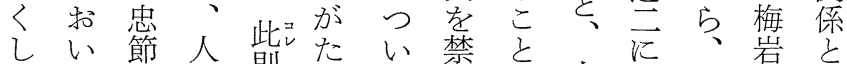

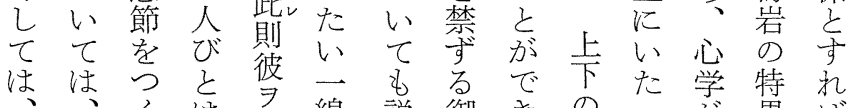

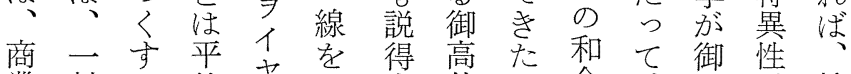
業対こ等 サひ方札の合、角㤎拙 社—々でンき肪の、で学御学あ稿

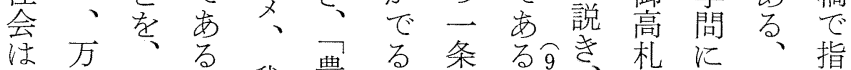

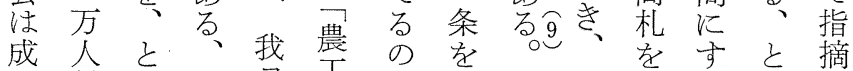

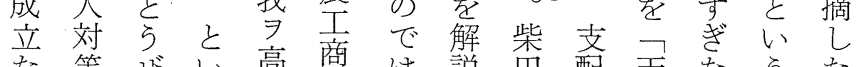
た等ぜい高商は説田配天ならた

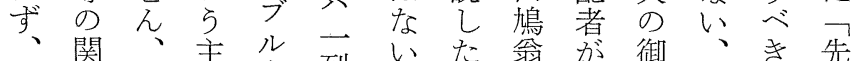

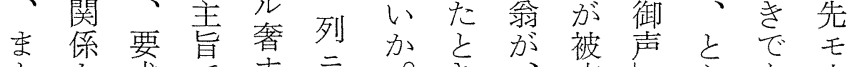

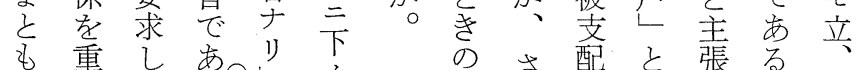

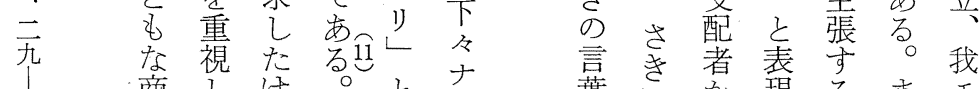

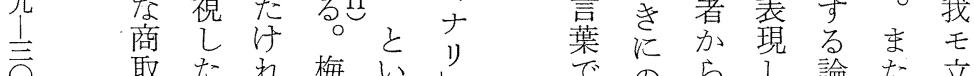

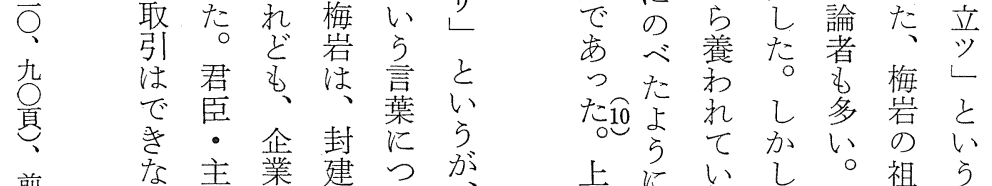

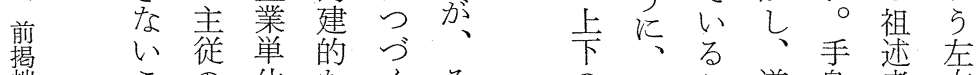
䇠この位なくそこ道島者右 著之上と階文机関売之元堵たの

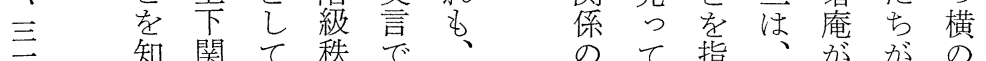
三 知関て 秩で、 のて 指、灾方の 


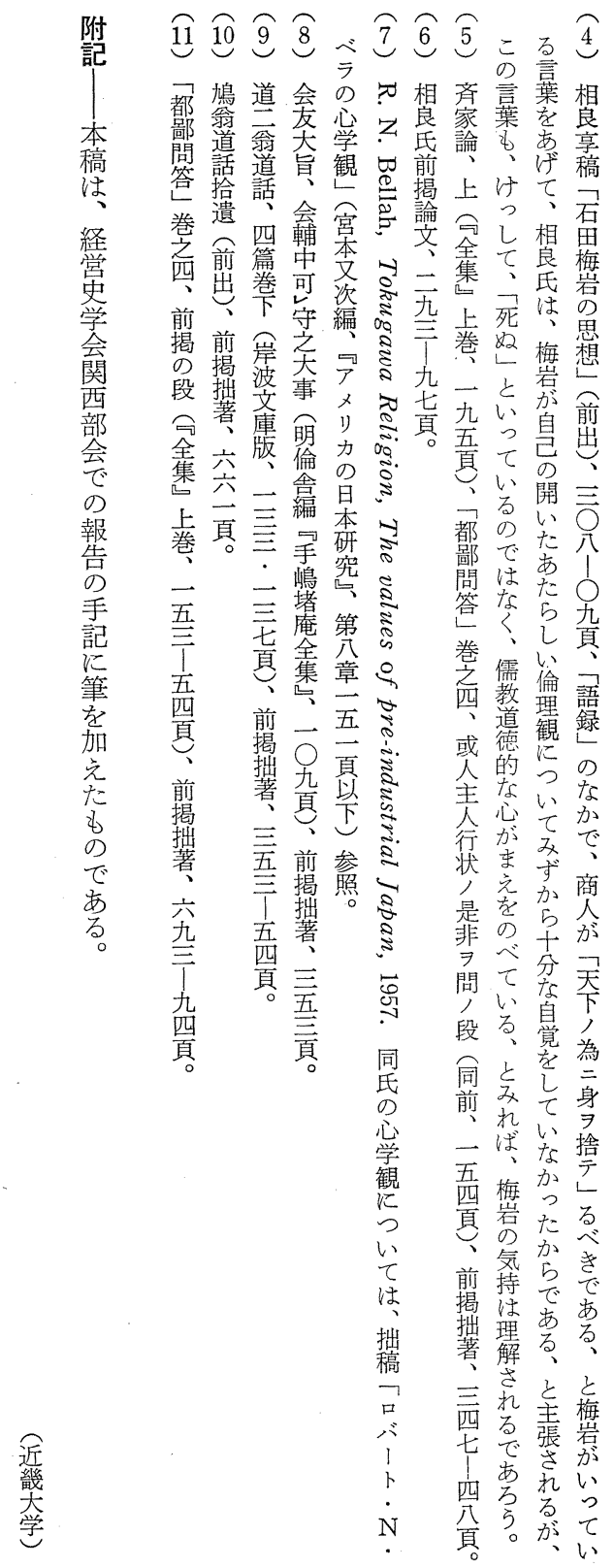




\title{
The Business Philosophy of Ishida Baigan
}

\author{
by \\ Yasukazu Takenaka \\ Kinki University
}

Ishida Baigan (1685-1744), who sought to develop a set of business ethics for merchants, asserted "to obtain business profits fairly is the proper practice of merchant living," and that this was legitimate because "merchants are vassals (social servants) of the street." Then, he stressed that the merchants ought to establish their own viewpoint about the social meaning of commercial transactions. Furthermore, asking what the true meaning of a transaction should be, he maintained that "true merchants are those who satisfy their customers as well as themselves,"-in other words, the transactions had to benefit both parties in buying and selling. Merchants, therefore, must respect their customers' interest. Thus, Baigan said that merchants had to cultivate the mind of the people in the realm. On the other hand, the thought of Baigan is characterized as "a philosophy of frugality," which he developed from his experience in a merchant house. This way of living was named "shimatsu" which implied the maintenance of a ballance between beginning and end. While shimatsu means economic rationalism in business philosophy, Baigan, having conceived the idea of frugality in a higher sense, recognized it as the basis of all moral virtues, and identified it as honesty. He said that one could lead a frugal life naturally when he was honest, and that he could recover the genuine honesty which was innated to every one whenever he put frugality into practice. Behind such a thought was the idea of "mottai-nai", a sort of national sentiment. This word implies literally the loss of appearance or manner proper to its nature, that is intolerable because it is contrary to the blessing offered by an invisible God. Then, Baigan explained, in brief, that frugality was "to abide by a law of existence." In such a thought, frugality is nothing but rationalization itself. 